


\section{In-Vessel Zircaloy \\ Oxidation/Hydrogen Generation \\ Behavior During Severe Accidents}

Manuscript Completed: August 1990

Date Published: September 1990

Prepared by

A. W. Cronenberg

Engineering Science and Analysis

8100 Mountain Rd. NE

Albuquerque, NM 87110

\section{Prepared for}

Division of Systems Research

Office of Nuclear Regulatory Research

U.S. Nuclear Regulatory Commission

Washington, DC 20555

NRC FIN 04-86-126 


\section{DISCLAIMER}

This report was prepared as an account of work sponsored by an agency of the United States Government. Neither the United States Government nor any agency Thereof, nor any of their employees, makes any warranty, express or implied, or assumes any legal liability or responsibility for the accuracy, completeness, or usefulness of any information, apparatus, product, or process disclosed, or represents that its use would not infringe privately owned rights. Reference herein to any specific commercial product, process, or service by trade name, trademark, manufacturer, or otherwise does not necessarily constitute or imply its endorsement, recommendation, or favoring by the United States Government or any agency thereof. The views and opinions of authors expressed herein do not necessarily state or reflect those of the United States Government or any agency thereof. 


\section{DISCLAIMER}

Portions of this document may be illegible in electronic image products. Images are produced from the best available original document. 



\section{AB STRACT}

In-vessel Zircaloy oxidation and hydrogen generation data from various U. S. Nuclear Regulatory Commission severe-fuel damage test programs are presented and compared, where the effects of Zircaloy melting, bundle reconfiguration, and bundle quenching by reflooding are assessed for common findings. The experiments evaluated include fuel bundles incorporating fresh and previously irradiated fuel rods, as well as control rods. Findings indicate that the extent of bundle oxidation is largely controlled by steam supply conditions and that high rates of hydrogen generation continued after melt formation and relocation. Likewise, no retardation of hydrogen generation was noted for experiments which incorporated control rods. Metallographic findings indicate extensive oxidation of once-molten Zircaloy bearing test debris. Such test results indicate no apparent limitations to Zircaloy oxidation for fuel bundles subjected to severe-accident coolant-boil off conditions. 
ABSTRACT

FOREWARD.

ix

EXECUTIVE SUMMARY.

1. INTRUDUCTION.................................... 1-1

1.1 References................................. 1-3

2. OVERVIEW OF HYDROGEN GENERATION ISSUES................... 2-1

2.1 BWR Mark -I and II Containment Issues................. 2-1

2.2 PWR and BWR Mark-III Containment Issues................ 2-2

2.3 BWR In-Vessel $\mathrm{H}_{2}$ Generation Issues................... $2-3$

2.4 References.................................. 2-6

3. PBF-SFD TEST SERIES............................. 3-1

3.1 Overview of Test Series.......................... 3-1

3.2 PBF-SFD Test Results............................ $3-3$

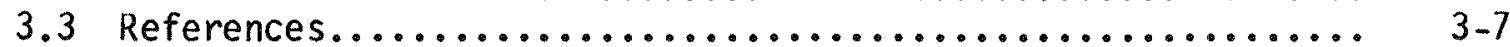

4. NRU-FLHT TEST SERIES.............................. $4-1$

4.1 Overview of Test Series............................ 4-1

4.2 NRU-FLHT Test Results.......................... $4-2$

4.3 References................................ $4-8$

5. ACRR-DR-4 Test..................................... $5-1$

5.1 Overview of Test............................ $5-1$

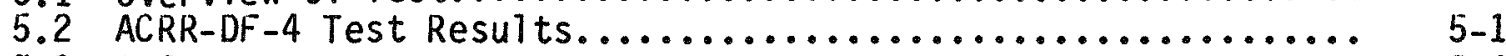

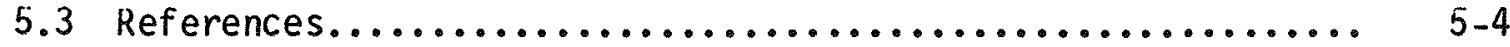

6. COMMON FINDINGS AND IMPACT OF TEST RESULTS................ $6-1$

6.1 Oxidation Behavior of Molten Zircaloy.................. 6-1

6.2 Fuel Bundle Reconfiguration Effects in BWR.............. 6-5

6.3 References................................ $6-14$

7. CONCLUSIONS................................... $7-1$ 


\section{LIST OF FIGURES}

Figure

Page

2-1 Illustration of BWR Mark -I type containment............. 2-2

2-2 Illustration of potential enhanced oxidation due to direct exposure of molten Zircaloy to steam.................... 2-4

2-2 Illustration of the IOCOR-BWR fuel assemble blockage/flow

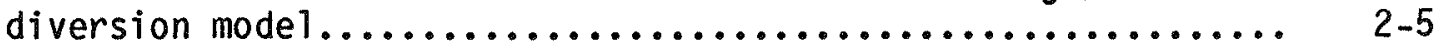

3-1 Illustration of the SFD fuel bundle geometry and effluent monitoring system (not to scale)...................... 3-2

3-2 Comparison of the PBF-SFD H2-generation test results....... 3-5

4-1 Illustration of the NRU-FLHT test fuel bundle geometry and effluent collection and monitoring system............. 4-2

4-2 Comparison of bundle inlet makeup flow (expressed in equivalent $\mathrm{H}_{2}$ production) versus the measured $\mathrm{H}_{2}$ response of the effluent noncondensable flowneter

4-3 Comparison of NRU-FLHT $\mathrm{H}_{2}$-generation history........... 4-5

4-4 Comparison of FLHT-4 fuel rod and carrier thermocoupledata.... 4-8

5-1 Cross section of the SNL-DF-4 test bundle showing control blade, channel box, and fuel rods. Al so shown is location in a BWR core which corresponds to the DF-4 design.......... 5-2

$5-2 \quad$ DF -4 hydrogen generation history $\ldots \ldots \ldots \ldots \ldots \ldots \ldots \ldots \ldots$

5-3 DF-4 post-test metallurgical evidence of extensive BWR channel box failure.

6-1 Il Iustration of potential enhanced oxidation due to direct

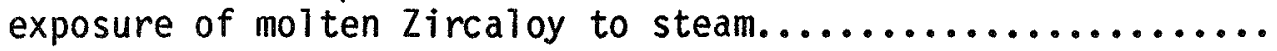

6-2 Pseudo-binary equilibrium phase diagram between $\mathrm{UO}_{2}$ and

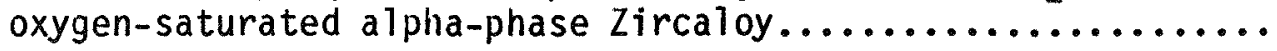

6-3 Comparison of the PFB-SFD thermocouple and on- 1 ine $\mathrm{H}_{2}$ generation data, to assess $\mathrm{H}_{2}$ partitioning before and after the initiation of $\alpha-\mathrm{Zr}(\mathrm{O}) / \mathrm{UO}_{2}$ eutectic melting at $2170 \mathrm{~K} \ldots .$.

6-4 Illustration of the original IDCOR BWR-MAPP blockage/coolant diversion hypothesis................................

6-5 Comparison of flow-area reduction noted in the PBF-SFD tests.. $6-7$

6-6 Illustration of isentropic compressible flow through a

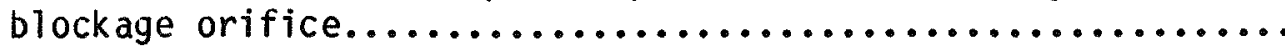


6-7 Summary of key melting points and eutectic temperatures that

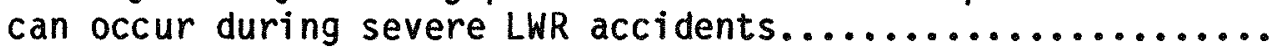

6-8 Illustration of asymmetric rod temperature conditions in the

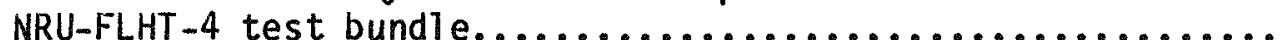

6-9 Illustration of asymmetric rod temperature conditions in the SFD $1-4$ test bundle................................ 6-11

$6-10 \quad$ Fe-Zr binary phase diagram........................ 6-12

6-11 Illustration of reestablished steam flow through a failed channel wall in a degraded/blocked BWR fuel assembiy......... 6-12 


\section{LIST OF TABLES}

Table

Page

1-1 Comparison of potential $\mathrm{H}_{2}$ generation in PWR and BWR

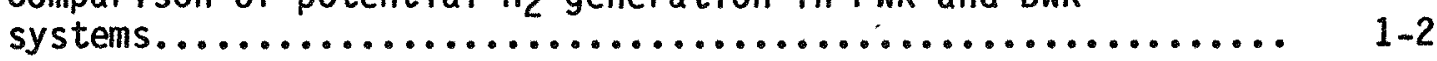

2-1 Inventory of containment types.................... 2-1

2-2 Hydrogen pressure in BWR Mark-I containments.............. 2-3

3-1 Summary of test conditions for the PBF-SFD severe fuel damage test series................................. 3-3

3-2 Summary of Zircaloy oxidation and hydrogen generation behavior noted in the PBF-SFD experiments.............. 3-4

3-3 Potential sources of hydrogen generation and metallographic

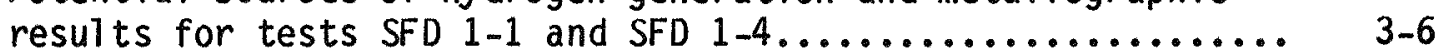

4-1 Ful1-iength high-temperature test matrix............. 4-3

4-2 Summary of Zircaloy oxidation and hydrogen generation behavior noted in the NRU-FLHT experiments............... 4-6

5-1 Summary of DF -4 test conditions.................... 5-2

6-1 Summary of melt effects on oxidation behavior............. 6-3

6-2 Summary of steam consumption by Zircaloy oxidation......... 6-8

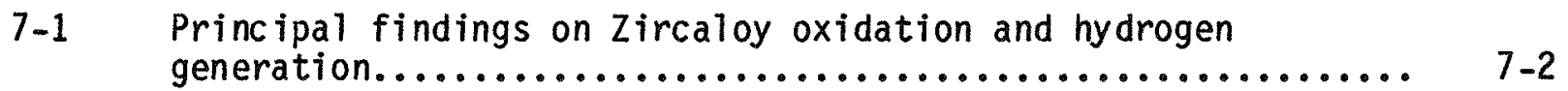




\section{FOREWORD}

This work was sponsored by the Commission's Small Business Innovation Research (SBIR) program, under contract NRC -04-86-126. 


\section{EXECUTIVE SUMMARY}

In this report Zircaloy-oxidation/H2-generation data from various Nuclear Regulatory sponsored severe-fuel damage (SFD) experiments are presented and compared for common findings. The experiments evaluated include the partial-length $(\approx 0.9 \mathrm{~m}) 32$-rod bundle tests performed in the Power Burst Facility (PBF), the ful1-length high-temperature (FLHT) tests performed in the National Research Universal (NRU) reactor at Chalk River (Canada), and the smaller $(0.5 \mathrm{~m}$ rod length) BWR DF-4 test conducted in the Annular Core Research Reactor (ACRR). Although these tests were conducted over a wide range of experiment conditions, a number of common findings are observed concerning the in-vessel $\mathrm{H}_{2}$ source term for severe accidents. The principal issues assessed relate to Zircaloy melting and bundle reconfiguration effects on hydrogen generation behavior, as well as Zircaloy oxidation/hydrogen generation behavior during accident mitigation conditions associated with core reflooding.

With respect to Zircaloy meit effects, a comparison of on-1ine hydrogen and cladding thermocouple data for the PBF, DF-4, and NRU-FLHT tests indicate that the major portion of hydrogen release occurred after melt temperatures were reached. Likewise, extensive post test metallurgraphy for these tests indicated that Zircaloy-bearing melt continued to oxidize during and following melt relocation. Arguments for cutoff or significantly deminished hydrogen generation upon Zircaloy melting and relocation are not supported by these data.

Bundle reconfiguration effects were assessed with respect to arguments that for BWR canned fuel assemblies, Zircaloy melting and debris relocation could lead to a completely blocked BWR fuel assembly and flow diversion to peripheral bundles, so that steam access and hydrogen production are terminated in degraded bundles at melt relocation. The validity of this hypothesis hinges on two key assumptions, total flow area blockage and an intact BWR channel box. The DF-4 experiment was specifically designed to address meltdown behavior of BWR structural and control components. Results of the DF-4 test indicate early channel box failure occurred due to attack by control rod melt, specifically eutectic interaction between the Zircaloy channel box and stainless-steel melt (the cladding material of the $\mathrm{B}_{4} \mathrm{C}$ control bladel. Metallurgical examination revealed that all but the lower 10-percent of the channel box had been destroyed by eutectic melt interaction.

The DF-4 fuel cladding thermocouple data also indicate that oxidation induced temperature escalation continued well after initiation of melting and relocation of the Zircaloy cladding, with continued steam access to the degraded bundle throughout the test. These findings are corroborated by post-test metallurgical observations of residual open flow area and a high degree of oxidation of once-molten/relocated Zircaloy debris. Partial

a. This work was sponsored by the U.S. Nuclear Regulatory Commission in cooperation with an international partnership which includes Belgium, Canada, Federal Republic of Germany, Finland, France, Italy, Japan, Netherlands, Republic of Korea, Spain, Sweden, Switzerland, United Kingdon, American Institute of Taiwan, and the Electric Power Research Institute. 
flow-area blockages were also noted for the PBF and NRU test bundles. Neither the DF-4, or any of the PBF and NRU tests, have indicated complete flow area blockage required for termination of steam access to degraded test bundles.

In summary, the in-pile test data presented in this report indicate (a) continued high rates of oxidation during and after zircaloy melting and relocation; (b) only partial flow area blockages; and (c) destruction of the BWR channel box by Zr-Fe eutectic melt interaction. Such behavior allows for continued steam access and $\mathrm{H}_{2}$ generation in degraded fuel bundles. observation from these tests thus do not indicate inherent 1 imitations on $\mathrm{H}_{2}$ generation during the initial stages of core degradation, other than that due to steam supply conditions. It is noted that this conclusion does not necessarily apply to the advanced late stages of a severe accident, where highly oxidized and reconfigured melt debris may ultimately form a large consolidated debris bed whose interior is impervious to steam access, similar to the situation revealed by the TMI -2 accident. 


\section{INTRODUCTION}

The primary source of hydrogen generation for severe accidents in light water reactors (LWRs) is from oxidation of Zircaloy fuel-rod cladding by steam, as represented by the following exothermic chemical reaction:

$$
2 \mathrm{H}_{2} \mathrm{O} \text { (steam) }+\mathrm{Zr}=2 \mathrm{H}_{2}+\mathrm{ZrO}_{2}+6700 \mathrm{~J} / \mathrm{g}-\mathrm{Zr}
$$

In a Pressurized Water Reactor (PWR) reactor like the Three Mile Island-Unit 2 (TMI-2), complete reaction of such cladding would produce about $1000 \mathrm{~kg}$ of hydrogen. A comparable Boiling Water Reactor (BWR) could produce nearly $2000 \mathrm{~kg}$ of hydrogen. Release of such large quantities of hydrogen to containment structures with an air atmosphere, can result in destructive deflagrations which could produce pressures in excess of containment design values $(1,2)$. Thus, an understanding of the processes affecting in-vessel $\mathrm{H}_{2}$ geñeration and ex-vessel burning during severe accidents, are of primary importance to LWR risk assessment studies.

The TMI-2 accident $c$ an be used to illustrate the hydrogen generation characteristics of the above reaction. Analysis of the data available from the TMI-2 accident indicate that about $460 \mathrm{~kg}$ of hydrogen was generated (3), equivalent to oxidation of approximately 45-percent of the inventory of Zircaloy cladding $(\approx 23,000 \mathrm{~kg})$. Noting that the uncovery length was about $8-\mathrm{ft}$ of the $12-\mathrm{ft}$ active core height, $460 \mathrm{~kg}-\mathrm{H}_{2}$ corresponds to about a 67-percent oxidation state of the exposed Zircaloy; which compares favorably with composition assay of core-debris samples retrieved from the damaged portion of the TMI-2 core (4). Of the $460 \mathrm{~kg}$ of $\mathrm{H}_{2}$ generated approximately $270 \mathrm{~kg}$ was released into the containment building, which burned in the presence of air resulting in a 28 psi pressure spike. The relatively large volume $\left(\approx 80,000 \mathrm{~m}^{3}\right)$ and high design pressure (60 psi) of the TMI-2 containment, however mitigated the consequences of hydrogen generation during this particular accident.

The potential for hydrogen generation during severe accidents is more pronounced for BWR plants, due to the added inventory of the Zircaioy channel box shrouding each fuel assembly. Table 1-1 presents a comparison of Zircaloy inventory and equivalent hydrogen production for the TMI-2 PWR and Brown's Ferry BWR plants. As indicated, BWRs on the average contain about two to three times the amount of Zircaloy as equivalent power PWRs.

Al though TMI-2 containment integrity was maintained, such was not the case at Chernobyl. Analysis of that accident $(5,6)$ indicated that failure of the Chernobyl confinement building occurred as a consequence of a reactivity-initiated fuel-coolant thermal interaction and rapid oxidation of Zircaloy melt, resulting in explosive steam generation which was exacerbated by a hydrogen-air explosion. Of particular note is that the Zircaloy cladding and pressure tubes comprise approximately 100 metric tons of Chernoby 1 core material, compared to about 20 to 25 metric tons of Zircaloy in typical PWRs like TMI -2 . 
TABLE 1-1. Comparison of potential $\mathrm{H}_{2}$ generation in PWR and BWR systems

\begin{tabular}{|c|c|c|}
\hline Parameter & TMI -2 & Brown's Ferry-2 \\
\hline $\begin{array}{l}\text { Reactor Type } \\
\text { Containment Type } \\
\text { Thermal Power, MWt }\end{array}$ & $\begin{array}{l}\text { PWR } \\
\text { Large Dry } \\
2770\end{array}$ & $\begin{array}{l}\text { BWR } \\
\text { Mark-I } \\
3300\end{array}$ \\
\hline $\begin{array}{l}\text { Cladding } \\
\text { Channel Box } \\
\text { Total } \\
\text { Potential } \mathrm{H}_{2} \text { Generation, } \mathrm{kg} \\
\text { Power Spec if ic } \mathrm{H}_{2}, \mathrm{~kg}-\mathrm{H}_{2} / \mathrm{MWt}\end{array}$ & $\begin{array}{l}24,000 \\
24,- \\
24,000 \\
1055 \\
0.38\end{array}$ & $\begin{array}{l}37,000 \\
25,000 \\
62,000 \\
2725 \\
0.82\end{array}$ \\
\hline
\end{tabular}

Recognizing that extensive Zircaloy oxidation and attendent hydrogen generation can occur during severe accidents, and that risk assessments and emergency response decisions require an adequate knowledge of governing phenomena, the U.S. Nuclear Regulatory Commission (NRC) initiated a Severe Fuel Damage (SFD) research program to investigate light water reactor core response to severe accidents. This program was later expanded to include a group of international partners. a A principal objective of this program is to provide an experimental data base and analytical methodology for decisions concerning the ability of existing or planned reactors to cope with severe accidents; where the cosequences of excessive hydrogen generation are of particular concern.

Experiments included in the NRC-SFD program and the subject of this report are the four partial-length $(=0.91 \mathrm{~m}) 32$-rod bundle tests performed in the Power Burst Facility (PBF) at the Idaho National Engineering Laboratory (7-9), three full-length high-temperature (FLHT) tests performed by BaEtelle Pacific Northwest Laboratory (PNL) in the National Research Universal (NRU) reactor at Chalk River, Canada (10-12), and the sma11-scale Damaged Fuel (DF-4) test $(13,14)$ conducted in the Annular Core Research Reactor (ACRR) at Sandia National Laboratories (SNL). In this report experimental data from these NRC sponsored severe fuel damage tests are assessed in terms of Zircaloy-oxidation and $\mathrm{H}_{2}$-generation behavior. Since an interpretation of such data in terms of hydrogen generation issues is a principal objective of this report, a review of central issues is presented in the following section.

a. Partners in the program include Belgium, Canada, Federal Republic of Germany, Finland, France, Italy, Japan, Netherlands, Republic of Korea, Spain, Sweden, Switzerland, United Kingdom, American Institute of Taiwan, and the Electric Power Research Institute. 


\subsection{References:}

1. W. R. Butler, C. G. Tinker, and L. S. Rubenstein, "Regulatory Perspective on Hydrogen Control for LWR Plants", Proc. of the Workshop on the Impact of Hydrogen on Water Reactor Safety, Vol. I, Albuquerque, NM, NUREG/CR-2017, SAND81-0661, (August 1981).

2. M. P. Sherman, M. Berman, and J. C. Cummings, "The Behavior of Hydrogen During Accidents in Light water Reactor", NUREG/CR-1561, SAND 80-1495, (August 1980).

3. J. 0. Henrie and A. K. Postma, "Lessons Learned from Hydrogen Generation and Burning During the TMI-2 Event", U.S. Department of Energy Report, GEND-061, (March 1987).

4. D. Akers et al., "TMI-2 Core Debris Grab Samples--Examination and Analysis (Part 1)", GEND-INF-075, (September 1986).

5. T. S. Kress, "The Chernobyl Accident Sequence," Nuclear Safety (28), pp. 1-9, (January-March 1987).

6. U. S. Department of Energy, "Analysis of the Chernoby 1-4 Accident", DOE-NE-0076, (November 1986).

7. D. J. Osetek, "Results of the Four PBF Severe Fuel Damage Tests"; Proc. 15th Water Reactor Safety Information Meeting, NUREG/CP-0090, Toctober 1987).

8. A. W. Cronenberg, R. W. Miller, and U. J. Osetek, "An Assessment of Hydrogen Generation for the PBF Severe Fuel Damage Scoping and 1-1 Tests", NUREG/CR-4866, EGG-2499, (Apri 1 1987).

9. A. W. Cronenberg, D. J. Osetek, and R. W. Miller, "Zircaloy Oxidation/Hydrogen Generation Behavior During Severe Accident Conditions", Proc. 24th National Heat Transfer Conf., Pittsburgh, PA, (August 9-12, 1987).

10. N. J. Lombardo, D. D. Lanning, and F. E. Panisko, "Data Report: Ful1-Length High-Temperature Experiment 2", PNL-6551, (April 1988).

11. D. D. Lanning, N. J. Lombardo, D. E. Fitzsimmons, W. K. Hensley, and F. E. Panisko, "Data Report: Full-Length High-Temperature Experiment 4", PNL-6368, (January 1988).

12. D. D. Lanning, N. J. Lombardo, D. E. Fitzsimmons, W. K. Hensley, and F. E. Panisko, "Data Report: Full-Length High-Temperature Experiment 5", PNL-6540, (Apri 1 1988). 
13. R. 0. Gauntt, R. D. Gasser, and L. J. Ott", "The DF-4 Fuel Damage Experiment in ACRR with a BWR Control Blade and Channel Box", NUREG/CR-4671, SAND86-1443, (November 1989).

14. R. Gauntt, R. Gasser, C. Fryer, and J. Walker, "Results and Phenomena Observed from the DF -4 BWR Control Blade Channel Box Test", Proc. Intern. ANS/ENS Conf. on Thermal Reactor Safety, Avignon, France Toctober 2-7,1988). 


\section{OVERVIEW OF HYDROGEN GENERATION ISSUES}

Containment designs for U.S. nuclear plants are often classified into three major categories, based on their ability to accommodate hydrogen and associated $\mathrm{H}_{2}$-air deflagrations (1). The three categories are listed in Table 2-1, while a discussion of hydrogen effects for each containment group is presented on the following subsections to this chapter.

TABLE 2-1. Inventory of containment types

\begin{tabular}{|c|c|c|c|c|}
\hline Category & Volume $\left(\mathrm{m}^{3}\right)$ & $\begin{array}{c}\text { Design } \\
\text { Pressure } \\
\text { (MPa) }\end{array}$ & Type & $\begin{array}{l}\text { Approximate } \\
\text { Number of } \\
\text { Operating and } \\
\text { Future Plants } \\
\end{array}$ \\
\hline Small & 8,000 & $0.30-0.42$ & $\begin{array}{l}\text { Mark -I/BWR } \\
\text { Mark-II/BWR }\end{array}$ & $\begin{array}{l}25 \\
10\end{array}$ \\
\hline Intermediate & 40,000 & $0.08-0.12$ & $\begin{array}{l}\text { Ice condenser/PWR } \\
\text { Mark-III/BWR }\end{array}$ & $\begin{array}{l}10 \\
21\end{array}$ \\
\hline Large & 80,000 & $0.30-0.42$ & Large Dry/PWR & 90 \\
\hline
\end{tabular}

\subsection{BWR Mark-I and -II Containment Issues}

Figure 2-1 presents a schematic of the Mark I BWR containment. Sma11 containments are also used in Mark-II BWR plants. Although hydrogen combustion is precluded in Mark-I and II containments by inerting with nitrogen, overpressurization by buildup of high-temperature hydrogen gas and steam could lead to excessive containment loading. Likewise, melt-through of the steel containment liner by corium debris, and attendant ingress of air into such hydrogen-filled containments, would al so pose a threat to containment failure.

The Brown's Ferry inventory of Zircaloy can be used to illustrate the hydrogen overpressurization potential for BWR Mark-I plants. As indicated in Table 2-2 the design pressure $(60 \mathrm{psi})$ would be exceeded at ful1 Zircaloy oxidation for el evated containment temperatures (T>500 K). To mitigate the effects of hydrogen overpressurization for Mark-I containments, drywell venting has been proposed $(2,3)$. The use of venting has been included in some plant-specific emergency operating procedures; however, accident sequence analysis $(4,5)$ indicates that for an Anticipated Transient Without Scram (ATWS), the accident progresses so rapidly that the operator may not have sufficient time to accomplish the necessary venting actions. For an ATWS sequence, early failure of the drywell containment would permit escape of fission products in the dryweil atmosphere to the secondary containment, without necessarily passing through the pressure-suppression pool. This is undesirable because the pressure-suppression pool is an effective method for fission product scrubbing. Important to the establishment of any venting procedures is an 
adequate understanding of the timing and amount of in-vessel hydrogen generated. Uncertainties in $\mathrm{H}_{2}$ source terin characterization can result in false or inadequate mitigation procedures, so that an experimental and analytical basis must be established for adequate quantification of the severe-accident hydrogen production.

\subsection{PWR and BWR Mark-III Containment Issues}

For noninerted/intermediate-size BWR, lark-III and ice condenser PWRS, containment design pressures could be exceeded if 25-percent (BWR) to about 60-percent (PWR) of the Zircaloy inventory is oxidized and the resultant $\mathrm{H}_{2}$ is released to the combustable air atmosphere of such containments (1). Igniter systems have therefore been installed in most intermediate size air-atmosphere containments, where controlled burning of $\mathrm{H}_{2}$ is used to mitigate against containment hydrogen buildup to explosive concentrations. For large-dry PWRs, hydrogen generation and combustion does not pose a threat to containment integrity. Thus, hydrogen generation issues generally center on BWRS, where several issues remain concerning in-vessel Zircaloy-oxidation behavior and hydrogen generation release rates.

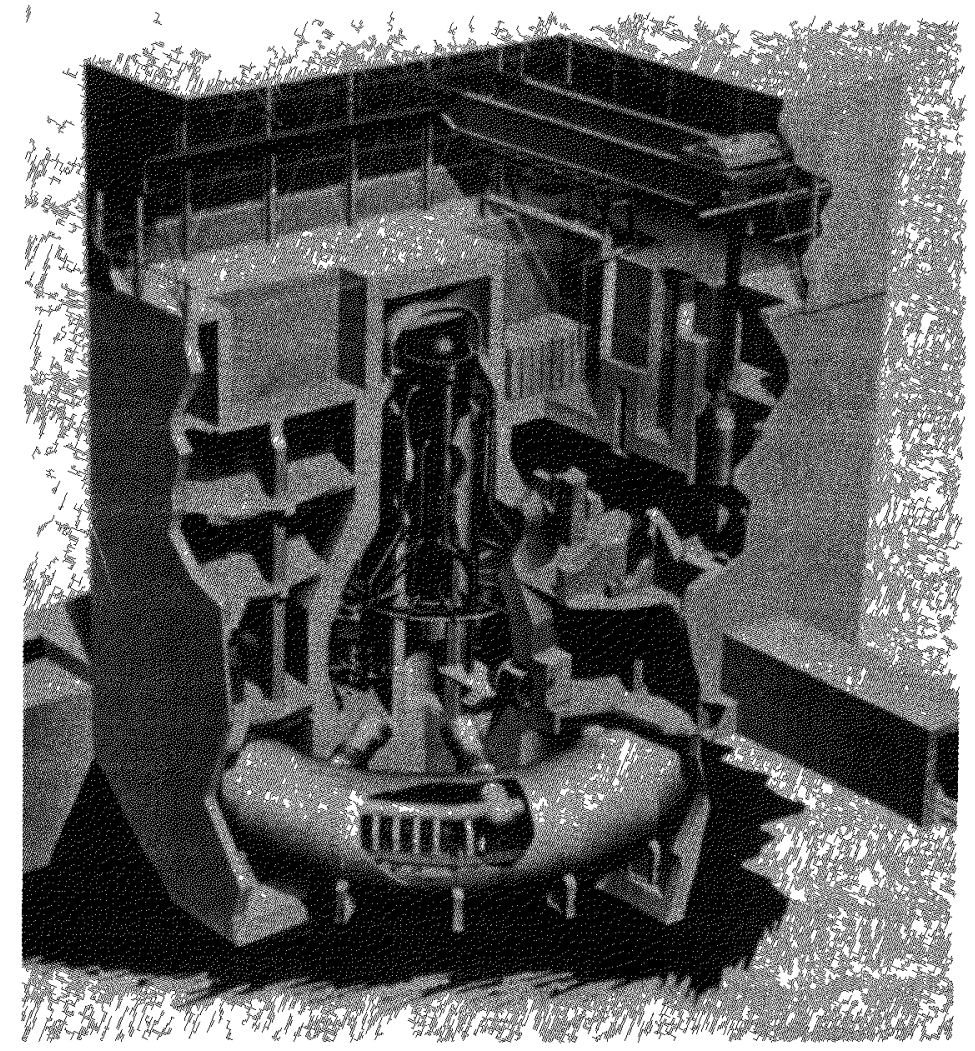

Figure 2-1. Illustration of BWR ilark-I type containment. 
TABLE 2-2. Hydrogen pressure in BWR ilark-I containments

Containment Design Parameters:

Volume $=8,000 \mathrm{~m}^{3}$

Pressure $=60 \mathrm{psi}$

Pressure Versus $\mathrm{H}_{2}$ Generation:

Containment Partial Pressure of $\mathrm{H}_{2}$ Gas, ${ }^{a}$ psi

Percent-Zr Reacted

25

50

100

\begin{tabular}{cc}
$T=300 \mathrm{~K}\left(81^{\circ} \mathrm{F}\right)$ & $I=500 \mathrm{~K}\left(440^{\circ} \mathrm{F}\right)$ \\
\hline $15 \mathrm{psi}$ & $25 \mathrm{psi}$ \\
$30 \mathrm{psi}$ & $50 \mathrm{psi}$ \\
$60 \mathrm{psi}$ & $100 \mathrm{psi}$
\end{tabular}

a. The calculated $i_{2}$ partial pressures are based on ideal gas behavior. The total containment pressure should include the presence of nitrogen inerting gas and steam.

\subsection{In-Vessel $\mathrm{H}_{2}$ Generation Issues}

As illustrated in Figure 2-2, oxidation of intact Zircaloy cladding is reasonably well understood, however once rod-like geometry is lost, the potential exists for destruction of the protective $\mathrm{ZrO}_{2}$ layer and direct exposure of molten $\alpha-\operatorname{Zr}(0)$ to steam, which may tend to accelerate the reaction. Un the other hand, molten Zircaloy relocation and dissolution of $\mathrm{UO}_{2}$ may reduce the effective surface-to-volume ratio, which could decrease the oxidation rate. These competing effects complicate the understanding of Zircaloy oxidation once core meltdown has cornmenced.

Loss-of-rod geometry upon melting of Zircaloy cladding can impact hydrogen generation behavior. For BWR canned fuel assemblies, it has been proposed by the Industry Degraded Core Rulemaking (IOCOR)a program that clad melting, fuel dissolution, and debris relocation will lead to blocked $B W R$ fuel assemblies $(0,7)$, as illustrated in Figure 2-3. Steam pressure

a. The IUCUR prograin was established in 1981 as an independent technical effort sponsored by the commercial nuclear power industry under the corporate auspices of the Atonic Industrial forum. The purpose of this program was to develop a technical position to assist in deciding whether or not changes in 1 icensing regulations are needed to reflect degraded core or core melt accidents. The program has now been incorporated into the severe accident analys is efforts, under the direction of the Electric Power Research Institute (EPRI). 
buildup below the blockage region was postulated to cause diversion of the residual coolant to adjacent unblocked assemblies, so that boiloff and further oxidation in a degraded BWR assembly were considered terminated at or near the $\alpha-\mathrm{Zr}(0) / \mathrm{UO}_{2}$ dissolution temperature $(\sim 2170 \mathrm{~K})$. This concept

of BWR fuel assembly degradation and associated hydrogen generation behavior was incorporated into the original formulation of the IDCOR sponsored BWR-MAAP code (8). MAAP calculational results for BWR accident sequences, assuming fuel assembly blockages upon Zircaloy melt relocation, generally result in low (< 25-percent) predictions of total Zircaloy oxidation. The validity of this hypothesis hinges on two key assumptions, total flow area blockage upon melt debris relocation and an intact BWR channel wall. These assumptions are examined in this report.

To help resolve these outstanding in-vessel $\mathrm{H}_{2}$ generation issues, Zircaloy-oxidation/hydrogen-generation data from the NRC severe fuel damage experiments are presented and compared here with respect to common findings.

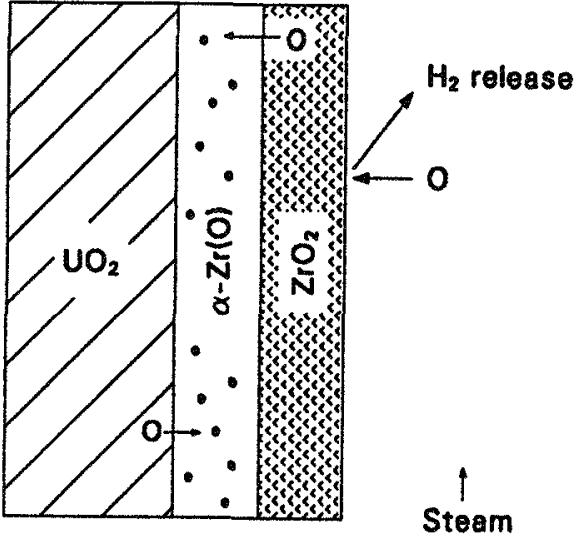

Intact rod geometry

Oxidation rate controlled by oxygen diffusion in thick $\mathrm{ZrO}_{2}$ layer

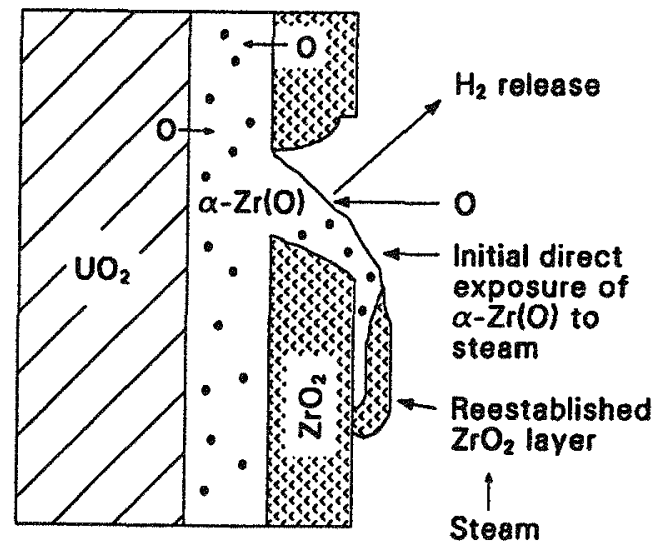

Disrupted rod geometry

Oxidetion can be enhanced by direct exposure of $\alpha-\operatorname{Zr}(0)$ to steam

Legend: $\quad \square \mathrm{Zu}_{2}$

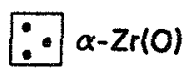

$\mathrm{ZrO}_{2}$ -O Oxygen diffusion

S267 AWC-0790-01 Figure 2-2. Illustration of potential enhanced Lry oxidation due to
direct exposure of molten 


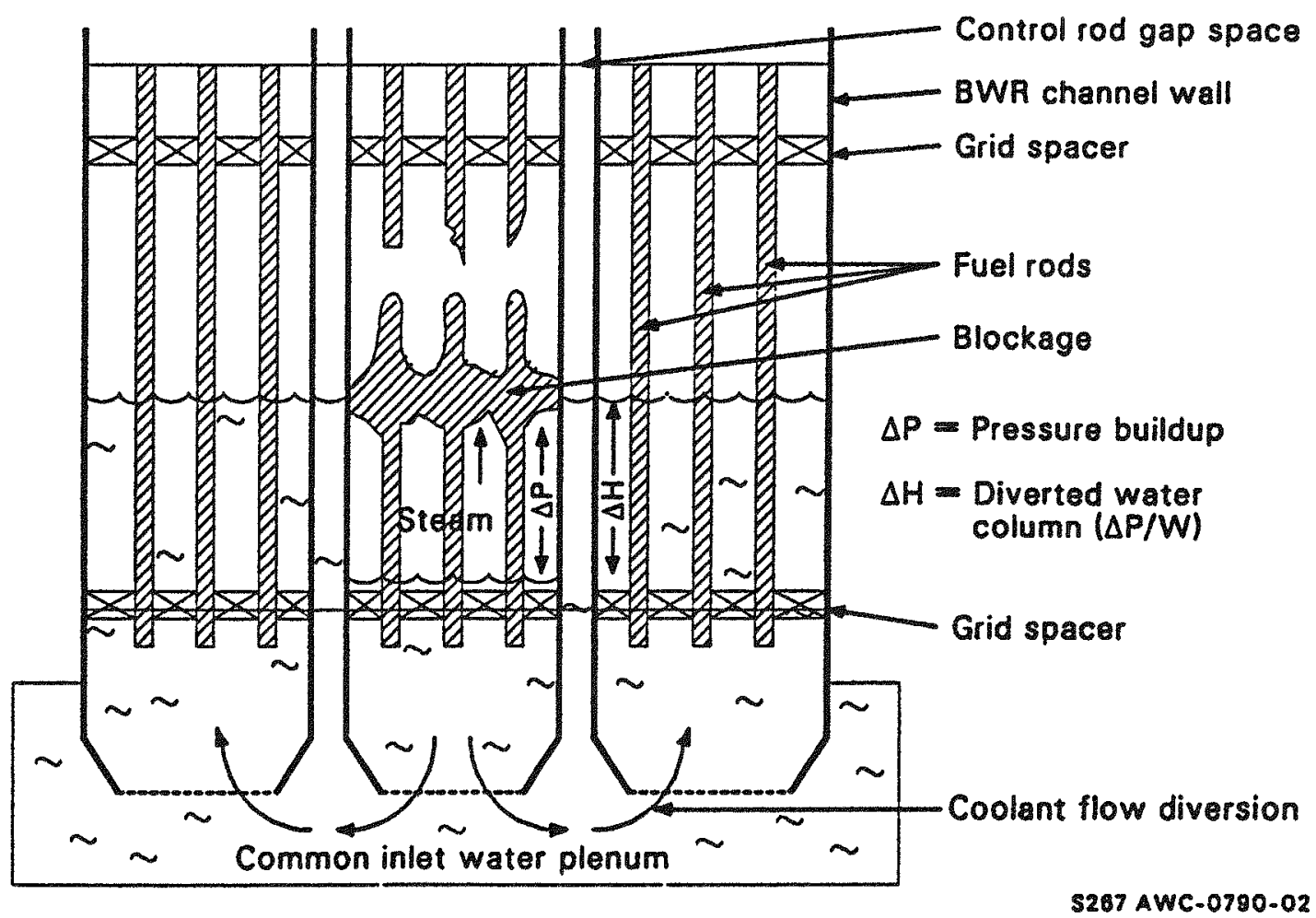

Figure 2-3. Illustration of the IDCOR-BWR fuel assembly blockage/flow diversion model. 
1. W. R. Butler, C. G. Tinker, and L. S. Rubenstein, "Regulatory Perspective on Hydrogen Control for LWR Plants", Proc. of the Workshop on the Impact of Hydrogen on Water Reactor Safety, Vol. 1, ATbuquerque, NM, NUREG/CR-2017, SAND81-0661, (August 1981).

2. Nucleonics Week, Vol. 28 (No. 36), McGraw Hil1 Pub. Co., (September 3, 1987).

3. U.S. Nuclear Regulatory Commission, "Reactor Risk Reference Document Appendix J12: NRC Staff Position on Containment Venting", Vol. 3, NUREG-1150, (February 1987).

4. D. J. Hansen, et al., "Containment Venting Analysis for the Peach Bottom Atomic Power Station", NUREG/CR-4696, EGG-2462, (December 1986).

5. R. J. Dallman, et al., "Severe Accident Sequence Analysis Program Anticipated Transient Without Scram Simulations for Browns Ferry Nuclear Plant Unit 1", NUREG/CR-4165, EGG-2379, (May 1987).

6. R. Henry, J. Gabor, M. Kenton, R. MacDonald, and A. Sharon, "Evaluations of Hydrogen Generation During Core Heatup with an Intact Geometry", Proc. Inter. Mtg. on LWR Severe Accident Evaluation, Cambri dge, MA, (August 28-September 1, 1983).

7. A. Sharon, "Comparison Between the PBF-SFD Fuel Bundle and a BWR Channel Behavior in Degraded Conditions", Proc. 24th National Heat Transfer Conf., Pittsburgh, PA, AIChE Symposium Series 257 (Vo1. 83), pp. 307-313, (August 9-17, 1987).

8. J. R. Gabor and R. E. Henry, "The MAAP-BWR Severe Accident Analysis Code", Proc. Intern. Mtg. on LWR Severe Accident Evaluation, Cambri dge, MA, (August 28-Sep tember 1, 1983). 


\section{PBF-SFD TEST SERIES}

The four PBF SFD in-pile experiments were inteyral in nature and designed to understand the synergistic coupled behavior of core materials under severe accident conditions, where fission product and aerosol release, transport, and deposition benavior, as well as hydrogen generation and melt interaction effects were studied. Detailed documentation of test results can be found in Rets. (1) through (9); here only test results associated with Zircaloy oxidation and hydrogen generation behavior are assessed.

\subsection{Overview uf Test Series}

Figure 3-1 presents a cross-sectional view of a typical test bundle and a schematic of the effluent monitoring system, while Table 3-1 summarizes overall test conditions. Each test bundle contained 32 rod positions, consisting of a mixture of fresh and/or previously irradiated fuel rods, with four Ag-In-Cd control rods in test SFD 1-4. The bundles consisted of 0.91 meter long Zircaloy-clad $\mathrm{UO}_{2}$ fuel rods, arranged in a $6 \times 6$ array with corner rods missing. Trace-irradiated fuel was used in the first and second tests, whereas high-burnup fuel was used in the SFD 1-3 and SFD 1-4 experiment. The fuel-destruction phase of each test was initiated by reducing coolant inlet flow to the bundle and increasing the reactor power, resulting in coolant boiloff, fuel rod overheating, and cladding oxidation. Once fuel rod temperatures in excess of about $1700 \mathrm{~K}$ were achieved, bundle heatup was driven by the exothermic reaction of the Zircaloy with steam, resulting in accelerated oxidation, Zircaloy melting, fuel dissolution and relocation, and release of hydrogen.

Each 32-rod test train was highly instrumented with fuel rod centerline, cladding, and steam thermocouples, as well as flowmeters, pressure sensors, and fission chambers for liquid-level detection. The test effluent was routed through an insulated line to the fission product and hydrogen collection system. Four separate measurements were used to assess for Lircaloy-oxidation/inydrogen-generation behavior, namely cladding therinocouple measurements, on-line gas analyses for hydrogen content, post-test determination of the collection tank gas contents for total hydrogen release, and post-test metallurgical assay of the extent and nature of zircaloy oxidation.

Cladding thermocouple data is indicative of the location and rate of Zircaloy oxidation. The cladding thermocouples were sheathed in Zircaloy and could measure accurately temperatures up to $\approx 2200 \mathrm{~K}$. Beyond this temperature the sheath melts and virtual junction are formed at lower and colder locations.

On-line gas-sampling data for hydrogen content was obtained using a Beckman thermal-conductivity analyzer, which measures the conductivity of the gas passing through the detector cell. Nitrogen carrier gas was used to sweep hydrogen from the liquid/vapor separator (see Figure 3-1) to the detector cell, while argon was used to purge gases from the bundle at the end of the test. In each test there was a significant delay time between the measured hydrogen concentration in the Beckinan meter and the test bundle event that caused it, Decause the test effluent must travel through approximately $50 \mathrm{~m}$ of piping before it reaches the Beckman meter. A fluid transport and mixing model was therefore developed, to infer real-time in-bundle hydrogen generation characteristics from the measured response of the Beckman meter. Details of the hydrogen transport model are discussed in Appendix $E$ of Ref. 3. 

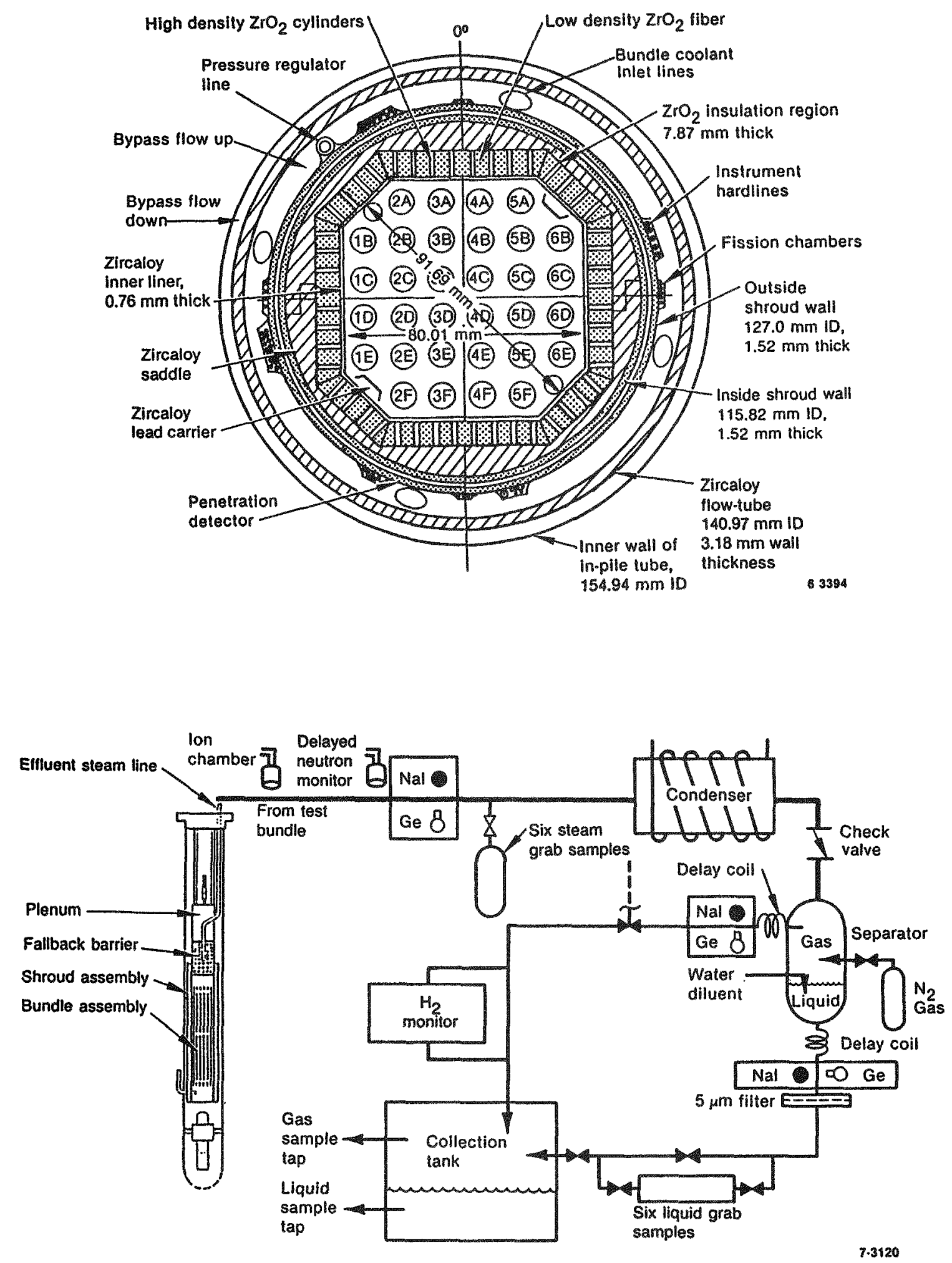

Figure 3-1. Illustration of the SFD fuel bundle geometry and effluent monitoring system (not to scale). 
TABLE 3-1. Summary of test conditions for the PBF-SFD severe fuel damage test series

\begin{tabular}{|c|c|c|c|c|}
\hline Test Conditions & SFD-ST & SFD $1-1$ & SFD $1-3$ & SFD $1-4$ \\
\hline Test Date & $0 c t-82$ & Sept-83 & Aug-84 & Feb-85 \\
\hline Active fuel length, $m$ & 0.91 & 0.91 & 0.91 & $0.91-1.0 \mathrm{~m}$ \\
\hline No. fresh fuel rods & 32 & 32 & 2 & $2(0.91 \mathrm{~m})$ \\
\hline No. irradiated rods & 0 & 0 & 26 & $26(1.0 \mathrm{~m})$ \\
\hline $\begin{array}{l}\text { No. control rods or } \\
\text { quide tubes }\end{array}$ & & 0 & $\begin{array}{l}4 \\
\text { quide tubes }\end{array}$ & $\begin{array}{l}4 \\
A q-I n-C d\end{array}$ \\
\hline $\begin{array}{l}\text { Nominal coolant } \\
\text { makeup rate, g/s }\end{array}$ & 16 & $\simeq 0.6$ & $0.6-15.5^{a}$ & $\simeq 0.6$ \\
\hline $\begin{array}{l}\text { Nominal system } \\
\text { pressure, } \mathrm{MPa}\end{array}$ & $\simeq 7$ & $\approx 7$ & 7 & $\simeq 7$ \\
\hline Heating rate, $\mathrm{K} / \mathrm{s}$ & $\begin{array}{c}0.1-0.15 \\
\text { below } \\
1300 \mathrm{~K}\end{array}$ & $\begin{array}{c}0.46 \text { below } \\
1300 \mathrm{~K} \\
2.9 \text { above } \\
1300 \mathrm{~K}\end{array}$ & $\begin{array}{l}0.64 \text { below } \\
1200 \mathrm{~K} \\
2.0 \text { above } \\
1200 \mathrm{~K}\end{array}$ & $\begin{array}{c}0.37 \text { below } \\
1200 \mathrm{~K} \\
1.6 \text { above } \\
1200 \mathrm{~K}\end{array}$ \\
\hline & $-m--m-m$ & $>5 \mathrm{~K} / \mathrm{s}$ above & $1700 \mathrm{~K}-\ldots$ & ---------- \\
\hline $\begin{array}{l}\text { Cool-down mode } \\
\text { Time at } T>1700 \mathrm{~K} \text {, s }\end{array}$ & $\begin{array}{l}\text { Fast-Quench } \\
\simeq \overline{000}\end{array}$ & $\begin{array}{l}\text { S7ow } \\
\simeq 600\end{array}$ & Slow & $\begin{aligned} & \text { Slow } \\
\simeq & 750\end{aligned}$ \\
\hline
\end{tabular}

a. Bundle depressurization and material relocation increased steaming rate to $15.5 \mathrm{~g} / \mathrm{s}$ for 11 seconds.

The third measurement involved assay of the collection tank by mass spectrometer analysis for gas content, and provides a measurement of the total hydrogen released during each test. The accuracy of the collection tank data was quantified from additional mass spectrometer measurements of $\mathrm{He}$ and $\mathrm{N}_{2}$ gas from the known $\mathrm{He}$ fill-gas inventory in the test rods and the $\mathrm{N}_{2}$ gas supplied to the separator. Results indicate that the mass spectrometer data are accurate to about \pm 15 -percent and offer the best estimate of total hydrogen generation.

Final assay of the nature of Zircaloy axidation was determined from metallographic examination of the Zircaloy-bearing debris from each bundle. Thickness measurement of the $\mathrm{ZrO}_{2}$ and $a-\mathrm{Zr}(0)$ layers in representative Lircaloy samples yields qualitative information on oxidation behavior of both solid and once-molten debris.

\subsection{PBF-SFD Test Results}

Table 3-2 summarizes the Zircaloy oxidation and $\mathrm{H}_{2}$ generation data for the four PBF-SFD experiments. It should be noted that for the SFD 1-3 test only collection tank data on total hydrogen generation is given. The absence of line data is due to inadvertent depressurization of the SFD 1-3 bundle, which resulted in loss of on-line effluent collection data. Loss of on-line hydrogen data for this test makes it difficult to draw definitive 
conclusions with respect to bundle heatup and degradation effects on real-time $\mathrm{H}_{2}$ generation; thus, the disucssion presented in this chapter is focused on the SFD ST, 1-1, and 1-4 tests results.

TABLE 3-2. Summary of Zircaloy oxidation and hydrogen generation behavior noted in the PBF-SFD experiments

\begin{tabular}{|c|c|c|c|c|c|}
\hline Parameters & Source of Data & SFD-ST & SFD $1-1$ & SFD 1-3 & SFD $1-4$ \\
\hline $\begin{array}{l}\text { Test } \\
\text { environment }\end{array}$ & $\begin{array}{l}\text {-Nominal makeup flow rate, } \mathrm{g} / \mathrm{s} \\
\text {-Nuclear power (peak), } \mathrm{kW} \\
\text {-Minimum liquid leve1, m }\end{array}$ & $\begin{array}{r}16 \\
93 \\
0.2\end{array}$ & $\begin{array}{r}\simeq 0.6 \\
35 \\
0.0\end{array}$ & $\begin{array}{l}\approx 0.6 \\
31.6 \\
0.0\end{array}$ & $\begin{array}{r}\approx 0.6 \\
27 \\
0.0\end{array}$ \\
\hline$-\cdots-\cdots$ & $-\cdots \cdots \cdots$ & $-\cdots$ & $-\cdots$ & $-\cdots$ & --- \\
\hline $\begin{array}{l}\text { Bundle } \\
\text { inventory of } \\
\text { Zircaloy as } \\
\text { equivalent- }-\mathrm{H}_{2}\end{array}$ & $\begin{array}{l}\text {-Intact cladding, } g \\
\text {-Inner liner, g } \\
\text {-Guide tubes, g } \\
\text {-Total, g }\end{array}$ & $\begin{array}{r}155 \\
73 \\
- \\
228\end{array}$ & $\begin{array}{r}155 \\
73 \\
- \\
228\end{array}$ & $\begin{array}{r}136 \\
73 \\
20 \\
229\end{array}$ & $\begin{array}{r}136 \\
73 \\
20 \\
229\end{array}$ \\
\hline$-\cdots-\cdots$ & $-\cdots-\cdots-\cdots$ & $-\cdots-$ & -- & $-\cdots$ & $-\cdots$ \\
\hline $\begin{array}{l}\text { Total } \\
\text { hydrogen } \\
(* \text { best }\end{array}$ & $\begin{array}{l}-\mathrm{H}_{2} \text { monitor, g } \\
\text {-Collection tank, } \mathrm{g} \\
\text { - Hetallography (Zry), }\end{array}$ & - & $\begin{array}{l}73 \\
64^{*} \pm 7\end{array}$ & $\overrightarrow{59} * \pm 7$ & $\begin{array}{l}98 \\
86^{*} \pm 12\end{array}$ \\
\hline estimate) & $\begin{array}{l}\text { Intact rods (Zry), g } \\
\text { Melt debris (Zry), g } \\
U_{2}, g \\
\text { Total, } g\end{array}$ & $\begin{array}{r}112 \\
60 \\
48 \\
172^{\star}\end{array}$ & $\begin{array}{c}37 \\
66.5 \\
0 \\
103.5\end{array}$ & $\begin{array}{l}- \\
-\end{array}$ & $\begin{array}{r}19 \\
95 \\
0 \\
114\end{array}$ \\
\hline-- & $-\cdots-\cdots-\cdots-\cdots$ & -- & $-\cdot-$ & -- & -- \\
\hline $\begin{array}{l}\text { Zircaloy } \\
\text { oxidation } \\
---_{-}\end{array}$ & $\begin{array}{l}\text {-Percent oxidation of } \\
\text { Zry inventorya } \\
---\ldots+\ldots\end{array}$ & $\begin{array}{l}75^{b} \\
--\end{array}$ & 28 & 26 & 38 \\
\hline $\begin{array}{l}\text { Timing of } \\
\mathrm{H}_{2} \text {-generation }\end{array}$ & $\begin{array}{l}\text {-Percent Zry oxidation } \\
\text { after } 2170 \mathrm{~K} \text {, noted from } \\
\text { thermocouple data }\end{array}$ & $=25-40$ & $\simeq 85$ & - & $>95$ \\
\hline
\end{tabular}

a. Based on bundle inventory of Zircaloy cladding, inner liner, and control-rod guide tubes for tests SFD $1-3$ and 1-4, and best-estimate collection tank $\mathrm{H}_{2}$-generation data.

b. Based on oxidation of Zircaloy only, i.e. 172-g/228-g $=0.75$. 
Figure 3-2 compares the integrated $\mathrm{H}_{2}$ generation history for the PBF-SFD ST, 1-1, and 1-4 experiments as a function of key test events. An important finding common to all tests is that $\mathrm{H}_{2}$ generation continued after on-set of $\mathrm{Zr}(0) / \mathrm{UO}_{2}$ liquefaction at $\approx 21 \% \mathrm{~K}$ and well into the cooldown pnase of each test. For the steam starved tests SFD 1-1 and 1-4, the vast majority of hydrogen generation occurred after the onset of $\mathrm{Lr} / \mathrm{UO}_{2}$ liquefaction and relocation, while for the steam-rich ST experinent most of the nydrogen was generated early in the test.

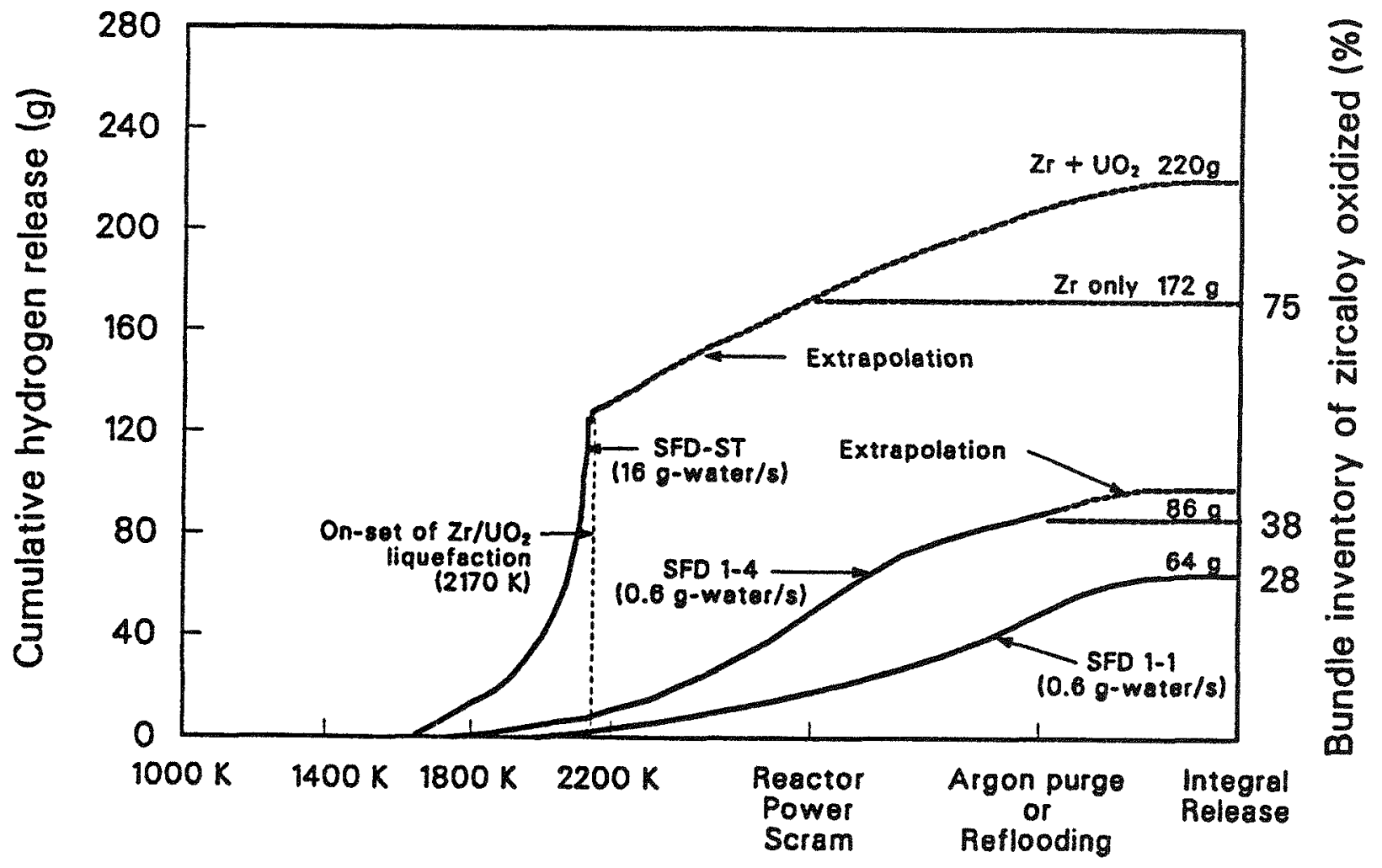

Sequence of key test events

\$48-WHT-889.02

Figure 3-2. Comparison of the PBF-SFD $\mathrm{H}_{2}$-generation test results. 
The timing of hydrogen generation for the three PBF-SFD experiments are also summarized in Table 3-2. The majority of $\mathrm{H}_{2}$-generation occurred after the onset of $\alpha-\operatorname{Zr}(0) / \mathrm{UO}_{2}$ 1iquefaction (at $\simeq 2170 \mathrm{~K}$ ) for the steam starved SFD 1-1 (85-percent) and 1-4 (>95-percent) tests, while for the steam-rich SFD-ST test most $\mathrm{H}_{2}$ (75-percent) was generated early in the test. This difference in partitioning is largely related to steam supply conditions. For the steam-rich ST experiment $(\simeq 16 \mathrm{~g}$-water/s) simultaneous oxidation occurred over most of the bundle length. For the steam-starved SFD $1-1 \quad(\approx 0.6 \mathrm{~g}$-water/s) and SFD $1-4 \quad(\approx 0.6 \mathrm{~g}$-water/s $)$ tests, transient oxidation was limited to a local region of the bundle, leaving a large portion of Zircaloy unoxidized after $2170 \mathrm{~K}$ was first reached and thus avajlable for later oxidation. It is also noted that the major portion of $\mathrm{H}_{2}$ generation for tests SFD 1-1 and 1-4 continued after Zircaloy melting/relocation was initiated.

Detailed metallography for all tests were obtained from $\mathrm{ZrO}_{2}$ and $\alpha-\operatorname{Zr}(0)$ thickness measurements of Zircaloy debris, where local sample measurements were used to ascribe representative values over a defined axial region of the bundle. Although errors are introduced by extrapolating discrete thickness measurements to whole-bundle oxidation characteristics, nevertheless such data illustrate overall trends in oxidation behavior. Commonality in PBF-SFD metallographic findings was also noted. Posttest examination of the test bundies revealed extensive oxidation of previously molten debris that was oxidized by steam during and following melt debris relocation. As indicated in Table 3-3, for the steam-starved SFD 1-1 and 1-4 tests, a higher degree of oxidation was noted for the once-molten Zircaloy bearing debris then that for still-intact cladding. For the steam-rich SFD-ST environment, essentially complete oxidation of both intact cladding and once-molten Zircaloy bearing debris was noted. The on-line hydrogen release and posttest metallographic data are therefore consistent, indicating adaquate time for Zircaloy debris to oxidize during and following melt relocation. .

TABLE 3-3. Potential sources of hydrogen generation and metallographic results for SFD $1-1$ and SFD 1-4

$M E=$ Metallographic Estimate

Source

Fuel rod cladding

Uxidized melt

Upper end caps

Lower end caps

Shroud inner liner

Lead carriers

Shroud Saddle

Control rod tubes
SFD 1-1 Hydrogen $(g)$

$\begin{array}{cc}\text { Upper Limit } & \text { ME } \\ 155 & 37.0 \\ 12 & 50 \\ 21 & 3 \\ 73 & 0.0 \\ 6 & 12 \\ 593 & 0.0 \\ \text { None } & 2 \\ \frac{}{860} & 104\end{array}$

SFD 1-4 Hydrogen (g)

\begin{tabular}{|c|c|}
\hline Upper Limit & ME \\
\hline 136 & $\begin{array}{l}19 \\
85\end{array}$ \\
\hline 12 & 0 \\
\hline 21 & 0 \\
\hline 73 & 9 \\
\hline 6 & 0 \\
\hline 593 & 0 \\
\hline 20 & 2 \\
\hline 861 & 114 \\
\hline
\end{tabular}


Further details of the metallurgical findings for the PBF-SFD tests are given in Refs. (1) through (4). Of particular interest is that some degree of oxidation was noted along the entire bundle length (except at lower elevations which were relatively cool), that both intact and relocated zircaloy melt experienced oxidation, and that even at the maximum blockage location oxidation of melt debris was apparent. It is also noted that post-test metallurgical assay of the PBF-SFD test bundles indicate that melt relocation and Zircaloy oxidation is a highly non-uniform process that occurs over an extended period of time. Evidence indicates that Zircaloy-bearing debris experienced both in-place oxidation, as well as reaction with steam during and following melt relocation. As a result adequate time appears available for Zircaloy debris to oxidize during and following melt relocation.

\subsection{References}

1. A. D. Knipe, S. A. Ploger, and D. J. Osetek, "PBF Severe Fuel Damage Scoping Test--Test Results Report", NUREG/CR-4683, EGG-2413, (August 1986).

2. Z. R. Martinson, D. A. Petti, and B. A. Cook, "PBF Severe Fuel Damage Test 1-1 Test Results Report", NUREG/CR-4684, EGG-2463, (October 1986).

3. D. A. Petti et al., "PBF Severe Fuel Damage Test 1-4 Test Results Report", NUREG/CR-5163, EGG-2542, (Apri1 1989).

4. Z. R. Martinson, et al., "PBF Severe Fuel Damage Test 1-3 Test Results Report", NUREG/CR-5354, EGG-2565, (October 1989).

5. D. J. Osetek, "Results of the Four PBF Severe Fuel Damage Tests", Proc. 15th NRC Water Reactor Safety Information Meeting, NUREG/CP-D009, (october 1987).

6. A. W. Cronenberg, R. W. Miller, and D. J. Osetek, "An Assessment of Hydrogen Generation for the PBF Severe Fuel Damage Scoping and 1-1 Tests", NUREG/CR-4866, EGG-2499, (Apri 1 1987).

7. A. W. Cronenberg, D. J. Osetek, and R. W. Miller, "Zircaloy Oxidation/Hydrogen Generation Behavior During Severe Accident Conditions", Proc. 24th National Heat Transfer Conf., Pittsburgh, PA, (August 9-12, 1987).

8. A. W. Cronenberg, R. 0. Gauntt, D. J. Osetek, and F. E. Panisko, "Severe Accident Lircaloy Oxidation/Hydrogen Generation Behavior Woted From In-Pile Test Data", Proc. 17th NRC Water Reactor Safety Information Meeting, NUREG/CP-0105, TOC tober 22-25, 1989).

9. A. W. Cronenberg, "In-Vessei Hydrogen Generation During Severe Accidents: Test Data Observations", J. Nucl. Tech., (February 1991). 


\section{NRU-FLHT TESTS}

A series of full-length high-temperature (FLHT) experiments are also being conducted under the direction of Battelle-Pacific Northwest Laboratories (PNL) in the National Research Universal (INRU) Reactor at Chalk River, Canada. This facility allows for in-pile testing of full-length (12-ft) comnercial fuel rods. The primary objective of the NRU-FLHT test series is to provide data on Lircaloy oxidation and fuel damage progression, for decay-heat/coolant-boilaway conditions leading to fuel meltdown. Additional data are obtained relative to fission product behavior, for test bundles that incorporate previously irradiated fuel rods. Detailed documentation of these tests can be found in Refs. (1) through (3), here only test results associated with Lircaloy oxidation and hydrogen generation behavior are assessed.

\subsection{Overview of Test Series:}

Figure 4-1 presents a cross-sectional view of a representative test bundle and the effluent collection and monitoring system. Table 4-1 summerizes overall test conditions. Each experiment consisted of 12-ft long Zircaloy-clad $\mathrm{UO}_{2}$-fuel rods, arranged in an array of twelve rod positions. Previously unirradiated fuel rods were used in the FLHT-2 test, whereas one high-burnup rod was incorporated into the FLHT-4 and FLHT-5 tests. The fuel-destruction phase of each experiment was initiated by reducing coolant inlet flow to the bundie at constant reactor power simulating decay-heat conditions, resulting in coolant boiloff, fuel rod overheating, Lircaloy cladding oxidation and failure. Once cladding temperatures in excess of about $1700 \mathrm{~K}$ were achieved, bundle heatup was driven by the exothermic reaction of the Zircaloy with steam, which induced accelerated oxidation, Zircaloy melting, and release of hydrogen.

An additional test (FLHT-O) is also planned, where fourteen full-length fuel rods surrounding a simulated section of a BWr control blade will be subjected to similar boiloff, Lircaloy oxidation, and bundle meltdown conditions. The date at which this test will be conducted is uncertain at this time.

The FLHT-2, 4, ana 5 test bundles were each instrumented with fuel rod cladding, carrier, liner, and steam thermocouples, as well as flowmeters and pressure sensors. The test effluent was routed through an insulated and heated line to the collection and monitoring system. Four separate measurements were used to assess Zry-oxidation/H2-generation behavior; namely cladding thermocouple data and tnree on-line hydrogen measurements. Additional information on overall Zircaloy melting, fuel dissolution, and test debris relocation were obtained from posttest examination of the test bundle.

The cladding thermocouple data is indicative of the location and rate of Zircaloy oxidation, as well as the liquid level within the bundle. The cladding thermocouples were sheathed in Zircaloy and could measure accurately temperatures up to about $2000 \mathrm{~K}$. The inscrument carriers and liner were also mounted with thermocouples to assess bundle peripheral temperatures. 

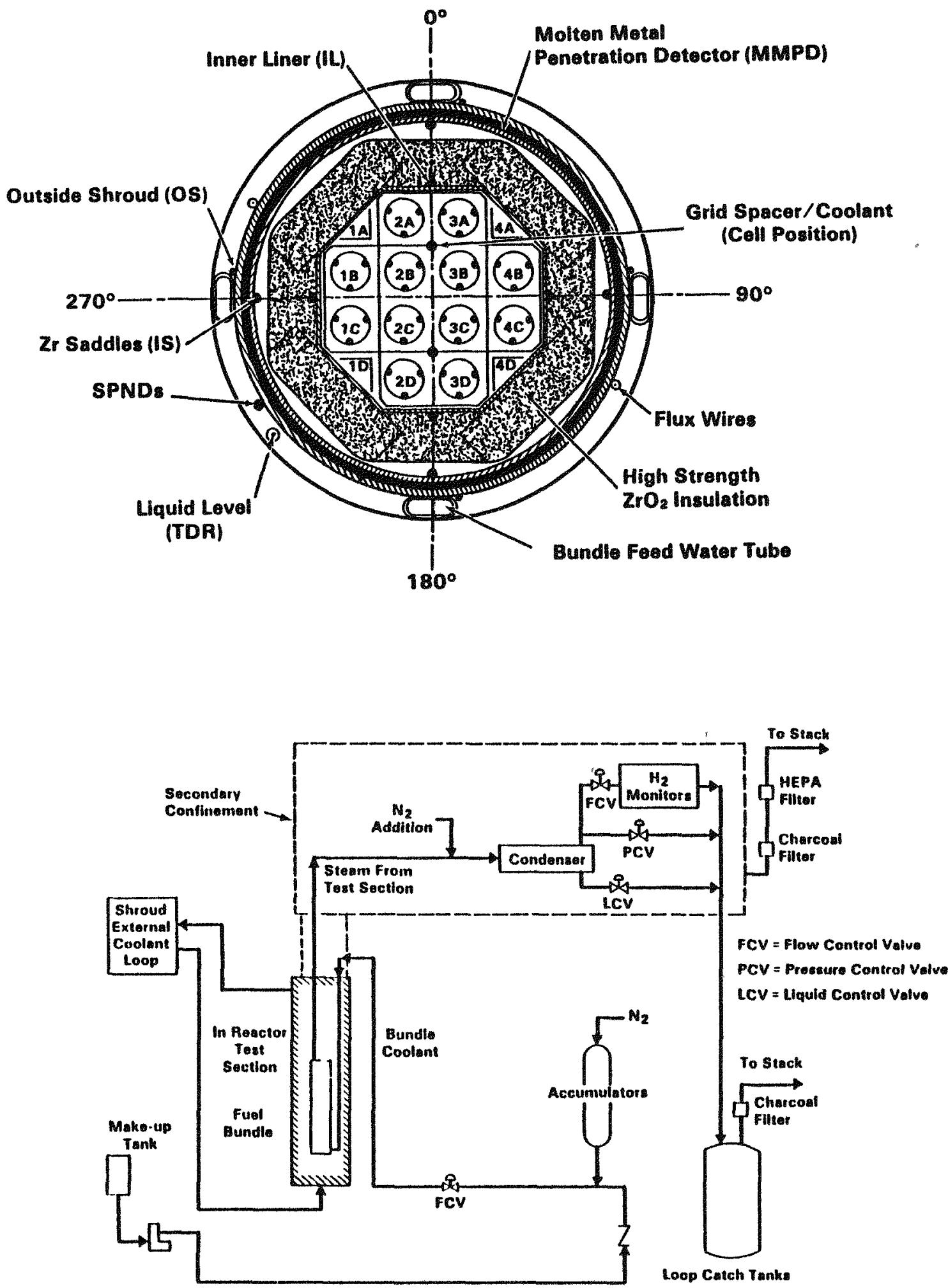

Figure 4-1. Illustration of the NRU-FLHT test fuel bundle geometry and effluent collection and monitoring system. 
TABLE 4-1. Full-1ength high temperature test matrix

\begin{tabular}{|c|c|c|c|}
\hline Test Conditions & FLHT -2 & FLHT -4 & FLHT -5 \\
\hline $\begin{array}{l}\text { Test Date } \\
\text { Active fuel length, } \mathrm{m} \\
\text { No. fresh fuel rods } \\
\text { No. irradiated rods } \\
\text { No. gamma thermometer rods } \\
\text { Nominal coolant makeup rate, } \mathrm{g} / \mathrm{s} \\
\text { Nominal system pressure, } \mathrm{WlPa} \\
\text { Heat generation rate, } \mathrm{kW} / \mathrm{ft} \text {-rod } \\
\text { Cool-down mode } \\
\text { Time at peak temperature }(T>1700 \mathrm{~K}) \text {, s }\end{array}$ & $\begin{array}{l}\text { Dec }-85 \\
3.0 \\
12 \\
0 \\
0 \\
1.4 \\
1.38 \\
0.16 \\
\text { Siow } \\
=250\end{array}$ & $\begin{array}{l}\text { Aug-86 } \\
3.6 \\
10 \\
1 \\
1 \\
1.26 \\
1.38 \\
0.17 \\
\text { S10W } \\
\simeq 1800\end{array}$ & $\begin{array}{l}\text { May }-87 \\
3.6 \\
10 \\
1 \\
1 \text { (dummy) } \\
1.23 \\
1.38 \\
0.23 \\
\text { Siow } \\
\simeq 3000\end{array}$ \\
\hline
\end{tabular}

Similar to the PBF experiments, a Beckinan thermal-conductivity meter was also used to assess $\mathrm{H}_{2}$ release, based on the measured conductivity of the gas passing through the detector cell. As was the case in the PBF experiments, there also exists a significant time delay in the FLHT tests between the measured $\mathrm{H}_{2}$ concentration in the Beckman meter and the test bundle event that caused it, due to transit and meter inertia. A comparison between measured peaks in the noncondensable flowmeter and thermal conductivity data, indicate a conductivity meter delay of about $500 \mathrm{~s}$, which however varies somewhat during the course of each test.

The second on-line $\mathrm{H}_{2}$ measurement for the FLHT-2 test was via a mass spectrometer, while a palladium $\mathrm{H}_{2}$-diffusion cell was used in the FLHT -4 and -5 experiments. The mass spectrometer allows for detection of the mass ratio of effluent gases $\left(\mathrm{H}_{2}, \mathrm{He}, \mathrm{N}_{2}, \mathrm{H}_{2} \mathrm{O}\right)$ to a nitrogen standard, while the palladium meter consists of a palladium memorane which has a relatively high diffusivity for hydrogen but is essentially opaque to heavier gases. Pressure measurements on the upstream and downstream side of the membrane can be used to infer the amount of $\mathrm{H}_{2}$ passed through the membrane. These detectors also exnibit a delayed response $(\simeq 200-250 \mathrm{~s})$ due to effluent transit delay from the bundle to the meter.

The most accurate real-time hydrogen release data were obtained from a system of turbine flow meters, which were used to assess the mass flowrate of noncondensable gases $\left(\mathrm{H}_{2}\right.$ and $\left.\mathrm{N}_{2}\right)$ in the effluent monitoring system. The noncondensable flowmeter provides essentially an instantaneous measurement of the rate of hydrogen production. This is evident from inspection of Figure $4-2$, where the FLHT-4 bundle makeup flow measured with an inlet flowmeter (expressed as equivalent hydrogen production), is compared with the $\mathrm{H}_{2}$-generation data based on the noncondensable flowmeter response. The comparison indicates complete consumption of makeup coolant after bundle boildown was achieved (after $1400 \mathrm{~s})$. The comparison also demonstrates that perturbations in the makeup flow are immediately seen in the noncondensable flowmeter response, so that the noncondensable flowmeter data provide an accurate real-time measurement of in-bundle $\mathrm{H}_{2}$-generation behavior. 


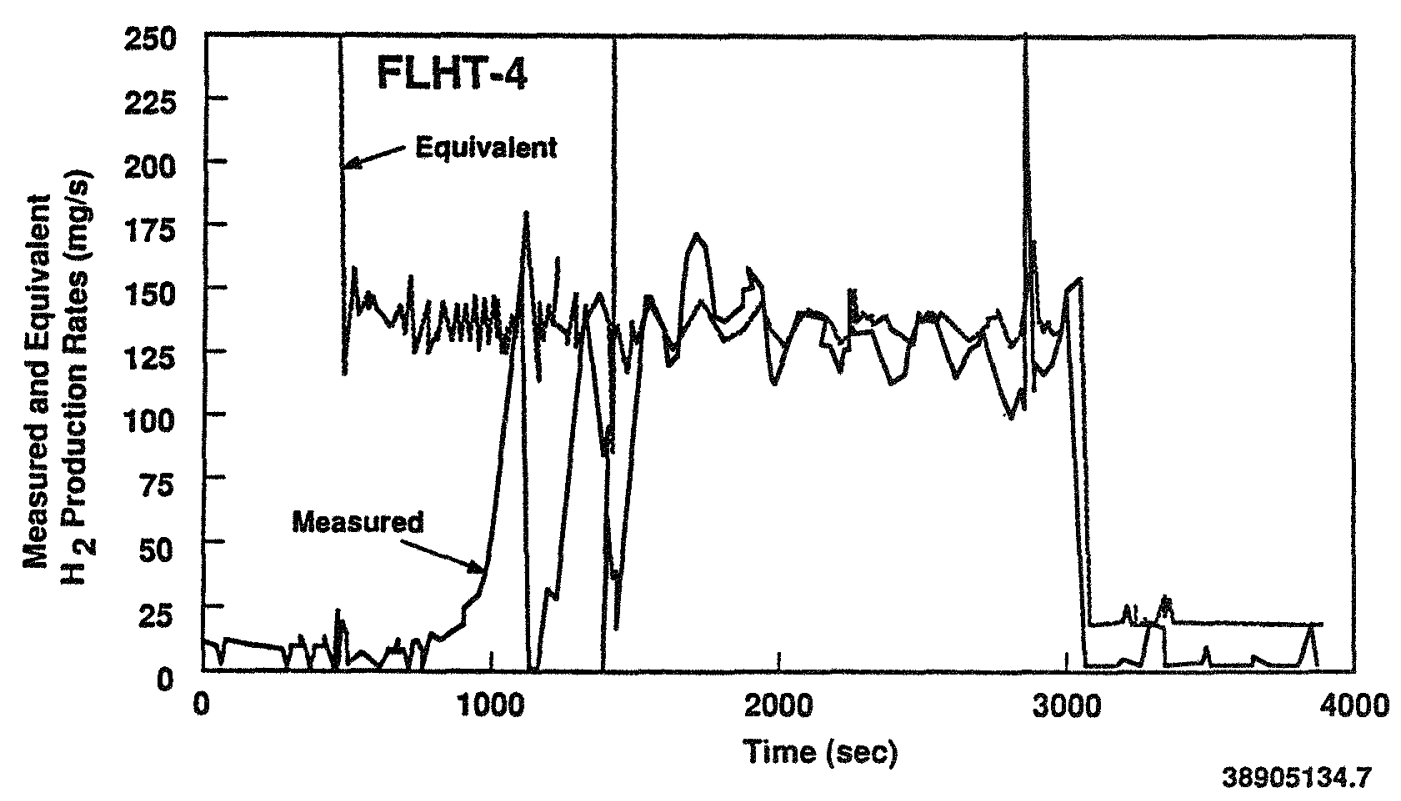

Figure 4-2. Comparison of bundle inlet makeup flow (expressed in equivalent $\mathrm{H}_{2}$ production) versus the measured $\mathrm{H}_{2}$ response of the effluent noncondensable flowineter.

\subsection{NRU-FLHT Test Results}

Figure 4-3 compares the on-line $\mathrm{H}_{2}$ generation history as a function of peak bundle temperatures and key test events for the three NRU-FLHT experiments based on noncondensable flowmeter data. In each test the vast majority of $\mathrm{H}_{2}$-generation occurred after onset of Zircaloy melting and $\mathrm{UO}_{2}$ dissolution at $\approx 2170 \mathrm{~K}$. For test FLHT-2 approximately 90-percent of the total hydrogen generated is indicated to have been produced after temperatures of $2170 \mathrm{~K}$ were first reached. For the FLHT -4 and FLHT-5 tests the value is 95-percent. These findings are in agreement with the PBF-SFD data, indicating that for steam-starved conditions the largest fraction of $\mathrm{H}_{2}$ generation occurs after initiation of $\alpha-\operatorname{Zr}(0)$ melting and associated fuel liquifaction.

Table 4-2 presents an overview of test conditions and summary of Zry-oxidation $/ \mathrm{H}_{2}$-generation test results. The noncondensable flowmeter provides essentially an instantaneous measurement of the hydrogen production and thus is the best-estimate indication of real-time in-bundle $\mathrm{H}_{2}$-generation characteristics. It is interesting to compare the test times over which autocatalztic oxidation was allowed (i.e. T>1700K) and the total amounts of $\mathrm{H}_{2}$ generated. Clearly the longer the test time the greater the amount of hydrogen produced. Noting that each gram of hydrogen produced corresponds to 9 grams of coolant makeup flow, the fraction $(F)$ of makeup flow consumed in oxidation can be expressed as:

$$
F=\frac{M_{H}}{(W F)(1 / 9)(t)}
$$


where

$$
\begin{aligned}
& M_{H}=\text { mass } H_{2} \text { produced, } g \\
& M F=\text { nominal makeup flow rate, } g / \mathrm{s} \\
& t=\text { test time above } 1700 \mathrm{~K}, \mathrm{~s}
\end{aligned}
$$

Using noncondensable flowneter data, it can be seen that complete stean (makeup flow) consumption occurred for tine FLHT-2 experiment, whereas the percent conversions of steam to hydrogen are 83-percent for the FLHT-4 test and 96-percent for FLHT-5. Tnus, in all tests the vast majority of steam produced was consumed in zircaloy oxidation. With respect to the percent overall oxidation (see Table $4-2$; fifth horizontal column), the limited amount of oxidation noted in test FLHT-2 (15-percent) is due to early sutoff of stea!n supply, that is a test time of only $25 \mathrm{U}$ seconds at $T>1 / 00 \mathrm{~K}$. For tests FLHT -4 $(t=1800 \mathrm{~s})$ and FLHT-5 $\quad(t=3000 \mathrm{~s})$ the time at high temperatures was significantly longer, resulting in a much higher degree of oxidation above the minimum liquid level for these experiments (i.e. 89 and 100 percent oxidation respectively).

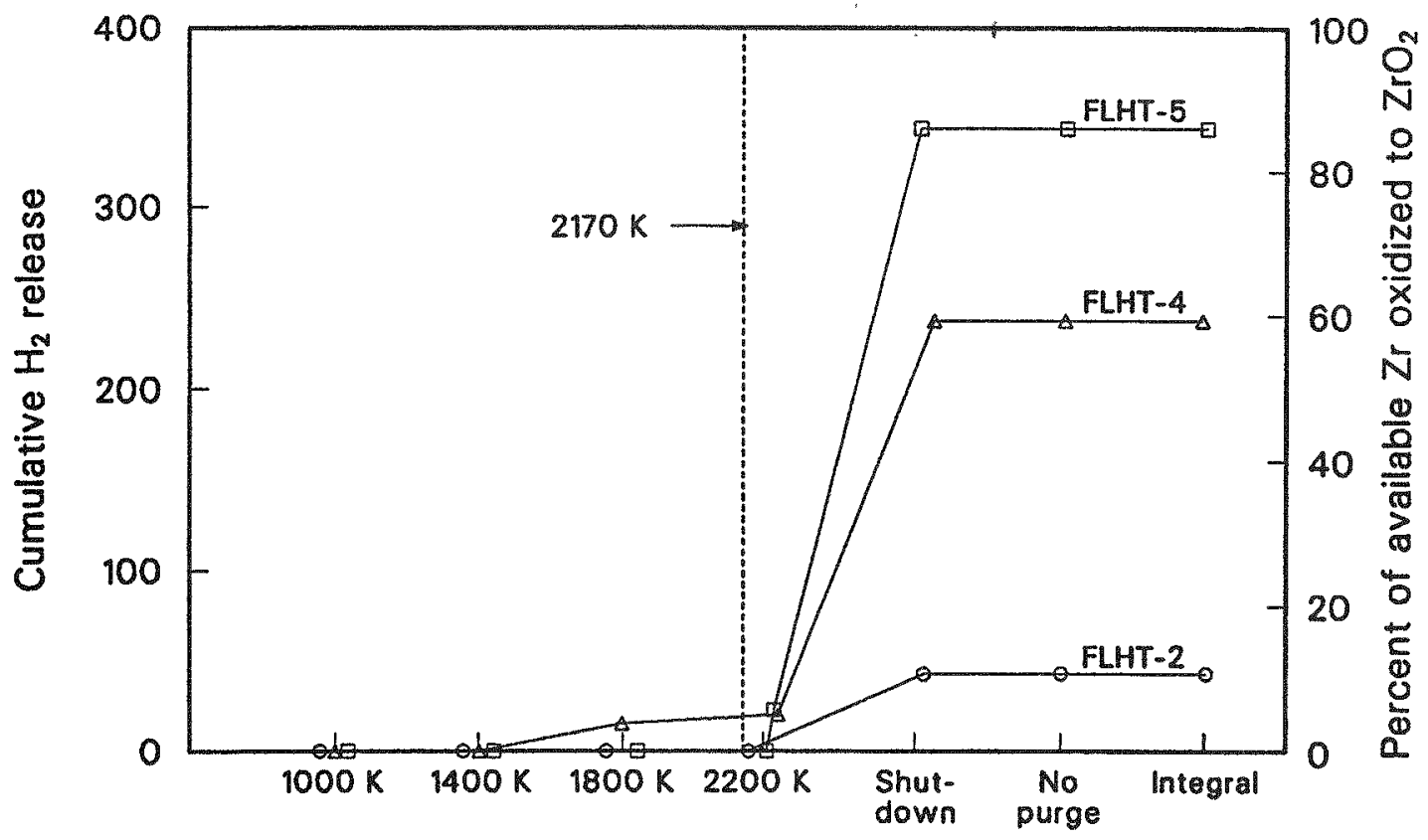

5287 AWC-0790-03

Figure 4-3. Comparison of NRU-FLHT hydrogen generation history. 
TABLE 4-2. Summary of Zircaloy oxidation and hydrogen generation behavior noted in the NRU-FLHT experiments

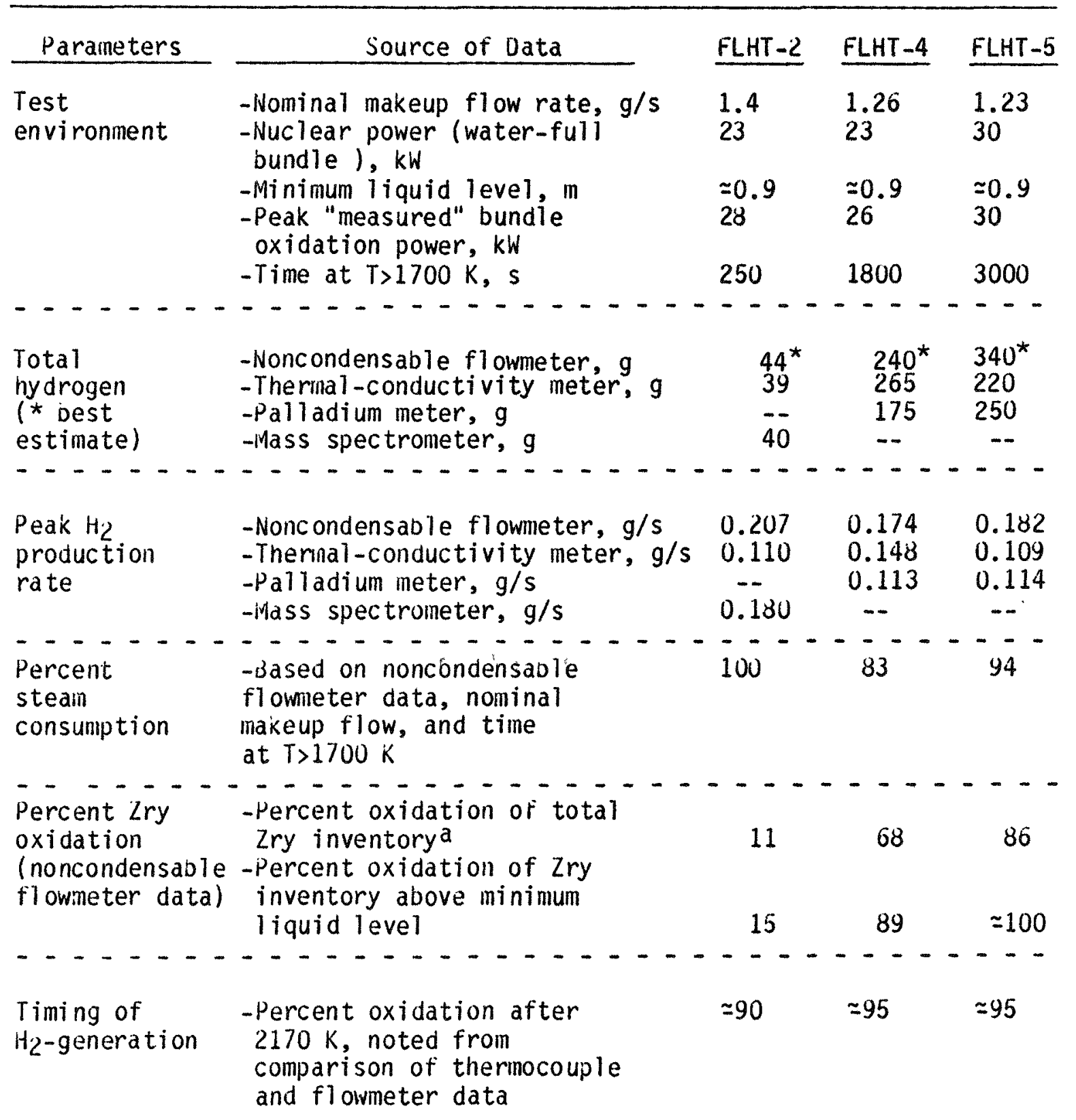

a. Complete oxidation of the total inventory of Zircaloy in the test bundle (up to top of active fuel length) to $\mathrm{ZrJ}_{2}$ would correspond to a total hydrogen production of about $392 \mathrm{~g}$. The carriers plus liner account for $\approx 40^{\circ}$-percent of the total bundle Lircaloy, while the cladding accounts for $\approx$ j4-percent. 
Al though detailed information on BWR fuel-bundle/control-rod meltdown behavior has been obtained from the partial-length ACRR DF-4 test and additional data will be available from the proposed full-length BWR FLHT-6 test, nevertheless evidence for BWR channel box oxidation and failure can be noted from the FLHT test data. As shown in Figure 4-1, the FLHT test bundles contained four corner $90^{\circ}$-angle instrument carriers, which were made of $0.05 \mathrm{~cm}$ thick Zircaloy. These Zircaloy carriers were mounted with thermocouples, yielding information on oxidation and failure behavior which can be used to infer BWR channel-box behavior in an oxidizing steam environment. A comparison on the FLHT-4 thermocouple data on carrier-4A at the $56 \mathrm{in}$. elevation and that for the adjacent rod-3A (see Figure 4-1) at the same elevation is shown in Figure 4-4. Although the carrier temperature lags that of the fuel rod by about $100 \mathrm{~K}$, it experienced similar oxidation driven heatup.

Posttest visual examination of the carriers also reveal melt failure and extensive oxidation, similar in nature to that of the cladding. Similar oxidation and failure of the instrument carriers was also noted in the FLHT-2 and FLHT-5 tests. The Zircaloy liner shrouding the test bundles likewise experienced oxidation induced failure, as was also noted in the PBF-SFU experiments. The implication of these findings is that oxidation driven heatup of a BWR Zircaloy channel box can be expected to closely follow that of the fuel rod cladding, so that channel box survival cannot be assured. Oxidation induced channel box failure would be of importance at BWR fuel assembly regions which are not in close proximity to control blades, while control blade/zircaloy eutetic interactions have been shown to result in early channel box failure at positions of control blade melt contact with Zircaloy, as discussed in the following chapter. 


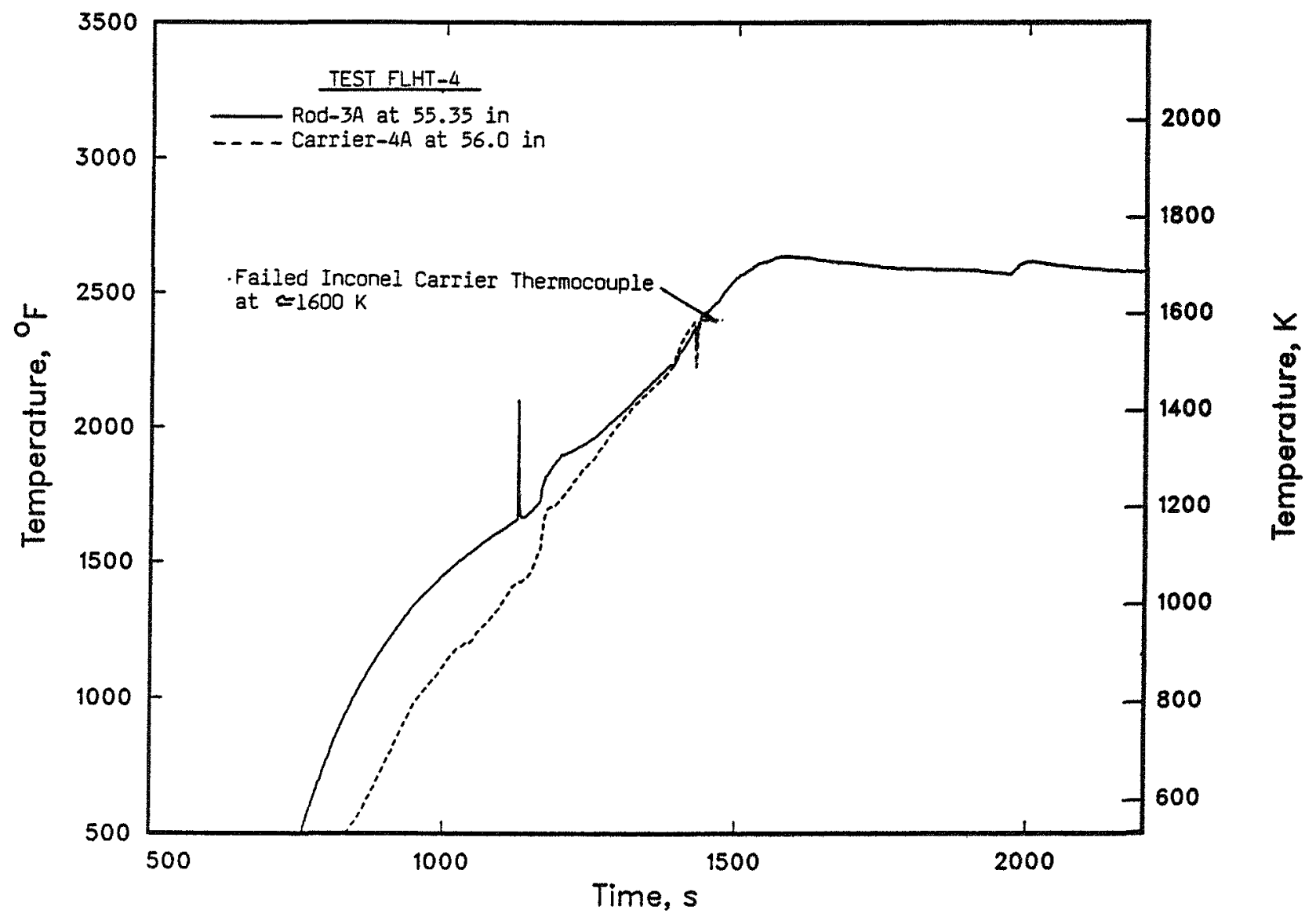

Figure 4-4. Comparison of FLHT-4 fuel rod and carrier thermocouple data.

\subsection{References:}

1. N. J. Lombardo, D. D. Lanning, and F. E. Panisko, "Data Report: Ful1-Length High-Temperature Experiment 2", PNL-6551, (April 1988).

2. D. D. Lanning, N. J. Lombardo, D. E. Fitzsimmons, W. K. Hensley, and F.E. Panisko, "Data Report: Fu11-Length High-Temperature Experiment 4", PNL-6368, (January 1988).

3. D. D. Lanning, N. J. Lombardo, D. E. Fitzsimmons, W. K. Hensley, and F. E. Panisko, "Data Report: Full-Length High-Temperature Experiment 5", PNL-6540, (Apri1 1988). 


\section{ACRR-Dr-4 TEST}

The UF-4 experiment was the fourth test in the Damaged Fuel (DF) experiment series being conducted in the Annular Core Research Reactor (ACRR) at Sandia National Laboratories (SIVL), and was designed to address the specific behavior of BWR structural and control components. The test included 14 Zircaloy-clad $\mathrm{UU}_{2}$ fuel rods $(0.5 \mathrm{~m}$ in lengtn) and structures representing the Zircaloy fuel canister and stainless-steel $\mathrm{Clad} \mathrm{B}_{4} \mathrm{C}$ control olade in a BWR core. Detailed infomation on the SNL-DF-4 test can be found in Refs. (1) and (2), here only data associated witn Zircaloy-oxidation/H2-generation in BWR bundles is presented.

\subsection{Overview of DF-4 Test:}

Figure 5-1 shows a cross section of the tip region of a BWR control blade, which was the basis for the geometry employed. Separate flow regions exist in the DF-4 representation for the fuel rod and the control blate regions. The region inside the rectangular channel box corresponds to the interstitial/control blade region which is outside the fuel canister in the actual BWR. In addition to thermocouples, a video record of damage progression was obtained by use of an end-on quartz window located above the test bundie. Continuous hydrogen production data was obtained from temperature measurements of a $\mathrm{CuO}_{-} \mathrm{H}_{2}$ reaction bed through which test effluent flowed. Additional information was obtained trom posttest non-destructive and destructive examination of the damaged bundle.

\subsection{DF -4 Test Results}

Tavle b-1 presents a surmary of test conditions. The initial fission heating of the test bundle caused the fuel temperatures to increase ac approximately $1.2 \mathrm{k} / \mathrm{s}$. At about $1800 \mathrm{~K}$, fuel neating rates increased to values in excess of $10 \mathrm{k} / \mathrm{s}$, driven by oxidation kinetics. Because of efficient radiative coupling, the unneated channel box and control slade lagged the fuel temperature by only about $50 \mathrm{~K}$, when bundle temperatures reached about $1520 \mathrm{~K}$. Blade tailure occurred at about lovU $\mathrm{K}$, which was roughly $100 \mathrm{~K}$ below the $1 / 00 \mathrm{~K}$ melting point of the stainless-steel cladding associated with tne $\mathrm{B}_{4} \mathrm{C}$ control blade. This result is consistent with eutectic interaction between iron and boron.

The video record of the experiment showed molten droplets of blade inaterial falling within the gap space between the blade and the Zircaloy channel box. The liquefied blade quickly relocated to the base of the bundle, freezing largely within the inside confines of the channel box. Shortly after control blade failure, an autocatalytic Zircaloy oxidation transient was observed, which resulted in rapidly increasing fuel and canister temperatures leading to melting of these materials. Relocation of molten Zircaloy from the fuel cladding and channel box occurred about 100 seconds after the initiation of the oxidation transient, resulting in additional accunulation of melt debris in the relatively cold lower portion of the test bundle. During chis time, sustained hydrogen generation from metal/steam oxidation reaction was detected. 
During the test complete consumption of cuo occurred, so that the $\mathrm{H}_{2}$-generation rate curve had to be extrapolated to metallalugrical assay of Zircaloy oxidation to $\alpha-\mathrm{Zr}(0)$ and $\mathrm{ZrO}_{2}$. Metallurgical results indicate a total of $38 \mathrm{~g} \mathrm{H}$-generation, which corresponds to an oxidation state of approximately 33-percent of the bundle inventory of Zircaloy (cladding plus channel box). As indicated in Figure 5-2, more then half the hydrogen ultimately produced was generated after major melt relocation. The DF-4 observations of continued $\mathrm{H}_{2}$-generation during and following melt relocation are in agreement with observations from the PBF-SFD and NRU-FLHT tests.

As shown in Figure 5-3, post-test metaliurgical examination of the test bundle revealed that all but the lower 10-percent of the channel box had melted, leaving only slight traces of any oxide channel box remnants in the upper regions of the bundle. Early channel box destruction apparentiy provided an open pathway for continued steam access to the upper regions of the degraded test bundle throughout the test transient.

The DF-4 observations of BWR Lircaloy channel box oxidation and failure are in basic agreement with resuits of the CORA-BWR absorber rod experiments $(3,4)$ indicating channel box failure due to a combination of Fe-Zr eutectic interaction and Zircaloy oxidation.

\subsection{References}

1. R. 0. Gauntt, R. D. Gasser, and L. J. Ott, "The DF-4 Fuel Damage Experiment in ACRR with a BWR Control Blade and Channel Box", NUREG/CR-4671, SAND86-1443, (November 1989).

2. R. Gauntt, R. Gasser, C. Fryer, and. Walker, "Results and Phenomena Observed from the DF-4 BWR Control Blade Channel Box Test", Proc. Intern. ANS/ENS Conf. on Thermal Reactor Safety, Avignon, France, Toctober 2-7, 1988).

3. S. Hagen, P. Hofmann, G. Schanz, and L. Sepoid, "Results of the CORA Experiments on Severe Fuel Damage With and Without Absorber Material", Proc. 26th ASME/AIChE/ANS National Heat Transfer Conference, Philadelphia, PA, (August 6-9, 1989).

4. S. Hagen, P. Hofmann, and G. Schanz, "Out-of pile Experiments on the Meltdown Behavior of LWR Fuel Elements: Influence of Absorber Materials", Proc. Intern. ANS/ENS Conf. on Thermal Reactor Safety, Avignon, France, (october 2-1, 1988). 




Figure 5-3. DF-4 post-test metallurgical evidence of extensive BWR channel box failure. 


\section{IMPACT OF TEST RESULTS}

As discussed in the Introduction, the principal focus of this report is an assessment of hydrogen generation data with respect to issues concerning Zircaloy melting effects on overall oxidation behavior, fuel bundle reconfiguration effects which may alter oxidation characteristics in BWR cores, and $\mathrm{H}_{2}$ generation under coolant requenching or accident recovery conditions. These issues are assessed here, based on common findings noted from the NRC sponsored severe fuel damage (SFD) experiments.

\subsection{Uxidation Behavior of Molten Zircaloy}

During the early intact-rod geometry phase of a severe accident, Zircaloy oxidation is reasonably well understood, where oxygen diffusion through a $\mathrm{ZrO}_{2}$ surface layer dictates parabolic reaction kinetics. However, as illustrated in Figure 6-1, once Zircaloy melting and fuel dissolution commence, destruction of the protective $\mathrm{ZrO}_{2}$ layer may tend to accelerate the reaction. On the other hand melt formation may reduce the Zircaloy surface-to-volume ratio, which would tend to decrease the overall reaction process. Although these two competing effects complicate the understanding of oxidation behavior for melt conditions, common finding from the PBF, NRU, and DF -4 data are noted.



Disrupted rod geometry

Figure 6-1. Illustration of potential enhanced Zircaloy oxidation due to direct exposure of molten Zircaloy to steam. 
In any assessment of core meltdown behavior, it is important to consider the influence of low-melting point eutectics that may from and their effluence on core degradation phenomena. Zircaloy exhibits three melting points depending on its oxidation state and lattice structure, namely $2150 \mathrm{~K}$ for $\mathrm{B}-\mathrm{Zr}, 2250 \mathrm{~K}$ for $\alpha-\mathrm{Zr}(0)$, and $2950 \mathrm{~K}$ for $\mathrm{ZrO}_{2}$. When in contact with $\mathrm{UO}_{2}$ partially oxidized Zircaloy cladding will form a $a-Z r(0) / \mathrm{NO}_{2}$ based eutectic, with a liquefaction temperature of approximately $2170 \mathrm{~K}$, where the pseudo-binary phase diagram for $\alpha-\operatorname{Zr}(0)$ and $\mathrm{UO}_{2}$ is jllustrated in Figure 6-2. Thus, if good fuel/cladding contact occurs, fuel liquefaction and melt relocation will commence at about $2170 \mathrm{~K}$, which can alter the oxidation behavior of Lircaloy based melt.

Figure 6-3 compares the PBF-SFD 1-1 and 1-4 on-line hydrogen generation and cladding thermocouple data. The common trend noted is that the major portion of hydrogen generation occurred after the $\alpha-2 r(0) / \mathrm{U}_{2}$ liquefaction temperature $(\approx 2170 \mathrm{~K})$ was first reached at some position in the bundle. For the PBF-SFD 1-1 test about 2 grams of hydrogen were generated prior the the onset temperature for liquefaction compared to a total on-line $\mathrm{H}_{2}$ generation value of $73 \mathrm{~g}$ (or 64 grams based on collection tank tank). For the SFD 1-4 less than 5-percent of the total $\mathrm{H}_{2}$ generated occurred before $2170 \mathrm{~K}$ was first reached in the bundle.

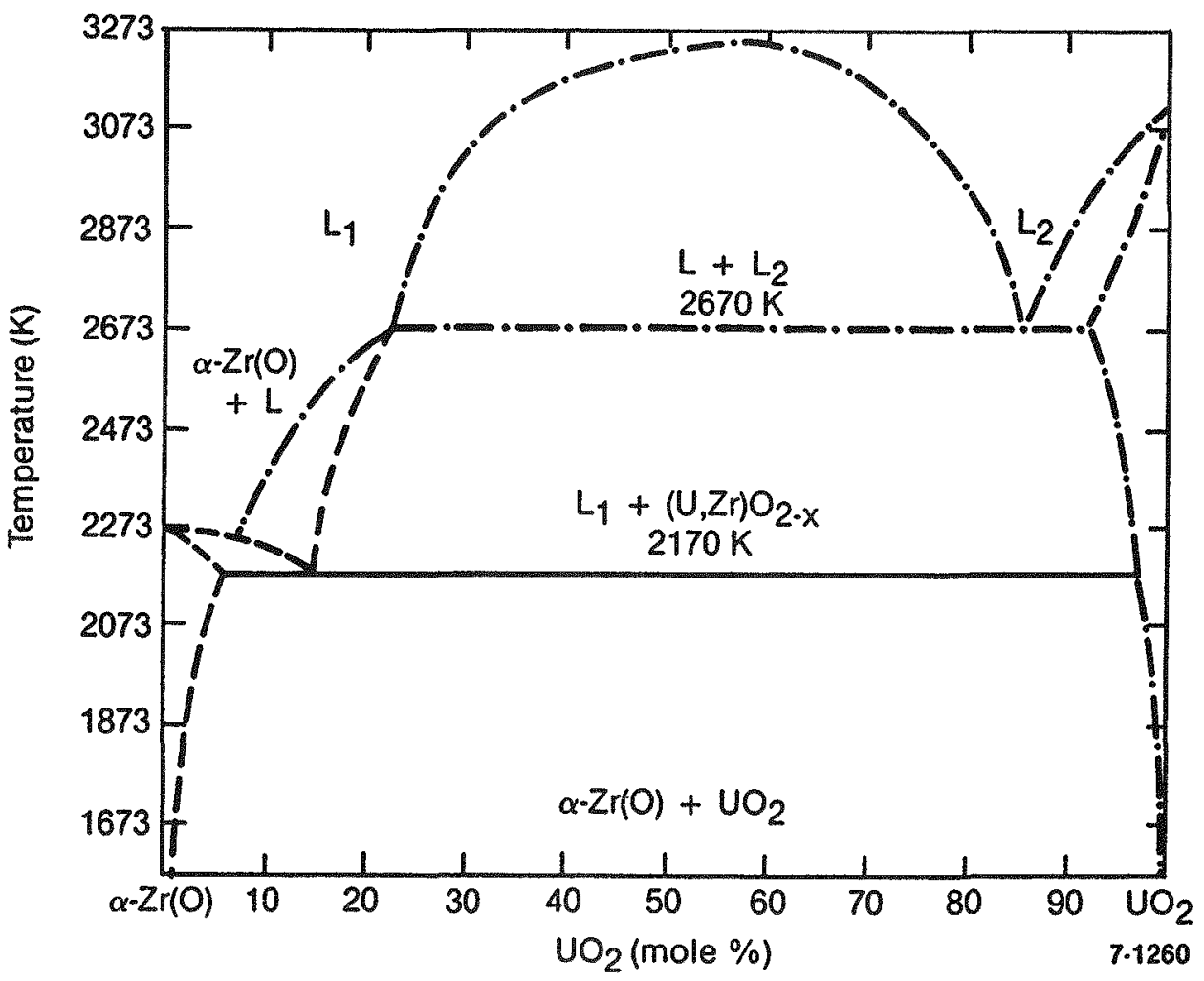

Figure 6-2. Pseudo-binary equilibrium phase diagram between $\mathrm{UO}_{2}$ and oxygen-saturated alpha-phase Zircaloy. 
It should be noted that the comparison of on-line thermocouple and integral hydrogen release data does not yield direct information on the partitioning of $\mathrm{H}_{2}$-generation with respect to that amount produced by oxidation of molten Zircaloy and that produced from still intact solid Zircaloy. Ideally, it would have been desirable to extract seperate measurements of hydrogen released from that portion of the bundle experiencing Zircaloy melting and the still solid portion of the bundle, thereby yielding seperate measurements of hydrogen generated from molten versus solid Zircaloy. However, because of the integral nature of the SFD experiments and the measurement of hydrogen release from the entire bundle, this could not be accomplished. Rather, it was only possible to assess from thermocouple data when Zircaloy melting first occurred at some location in the bundle and then partition $h_{2}$ generation before and after that time. Nevertheless, such a comparison does yeild insight into the question of whether or not significant hydrogen generation occurs after onset of fuel melting and melt-debris relocation. The data clearly indicate high amounts of hydrogen generation well into the meltdown/relocation phase of the SFD tests.

The NRU (see Figure 4-3) on-line data also indicates that the vast majority of the hydrogen was generated after onset of Zircaloy melting and fuel dissolution. For the FLHT-2 test approximately 90-percent of the total hydrogen generated is indicated to have occurred after temperatures of $2170 \mathrm{~K}$ were first reached at some axial position in the bundle. For the FLHT-4 and FLHT-5 tests the value is 95-percent. A similar trend is noted in Figure 5-2 for the DF-4 test.

Table 6-1 summarizes results with respect to the best estimate of the fraction of hydrogen generated after the $\alpha-\mathrm{Zr}(0) / \mathrm{UO}_{2}$ dissolution temperature was first reached in each of teh PBF, NRU and DF-4 tests. These data indicate the common trend of continued high rates of Zircaloy oxidation after melt generation. Only for the steam-rich PBF-SFD ST experiment is the majority of oxidation indicated to have occured before Zircaloy temperatures were reached. This difference in partitioning of hydrogen generation is 1 argely related to steam supply conditions. For the steam-rich ST experiment $(\simeq 16$ g-water/s) simultaneous oxidation occurred over most of the bundle length. For the steam-starved SFD experiments, transient oxidation was limited to a local region of the bundle, leaving a large portion of Zircaloy unoxidized after $2170 \mathrm{~K}$ was first reached and thus available for later oxidation.

TABLE 6-1. Summary of melt effects on oxidation behavior

\begin{tabular}{l} 
Test \\
\hline PBF-SFD ST \\
PBF-SFD $1-1$ \\
PBF-SFD ST \\
NRU-FLHT-2 \\
NRU-FLHT-4 \\
NRU-FLHT-5 \\
ACRR-DF-4
\end{tabular}

Steam Environment

Percent Uxidation after $2170 \mathrm{~K}$

Steam Rich

Steam Starved

Steam Starved

$25-40$

Steam Starved

Steam Starved

Steam Starved

Steam Starved

85

95

90

95

95

88 

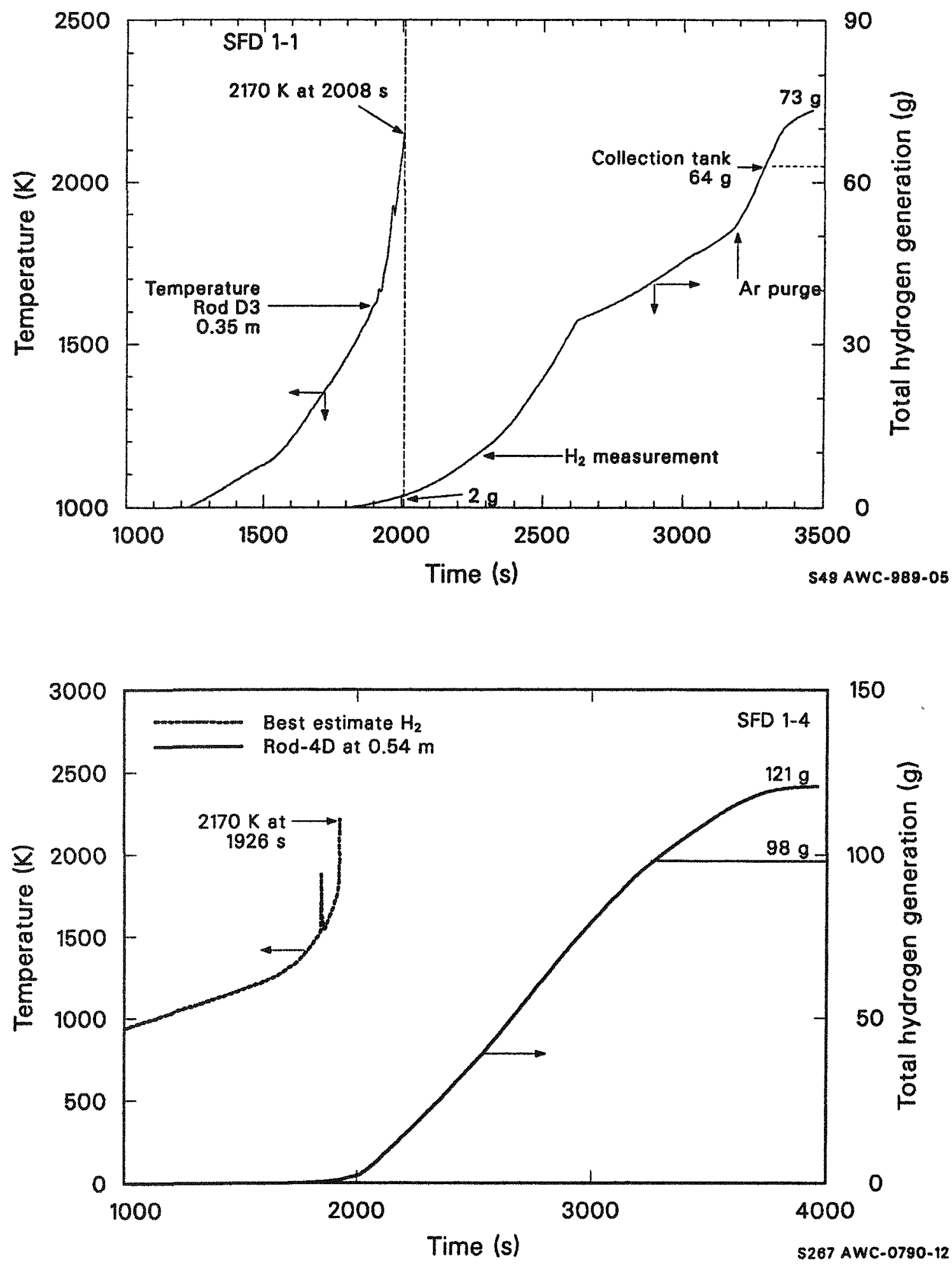

Figure 6-3. Comparison of the PBF-SFD thermocouple and on-1ine $\mathrm{H}_{2}$ generation data, to assess $\mathrm{H}_{2}$ partitioning before and after the initiation of $\alpha-\mathrm{Zr}(0) / \mathrm{UO}_{2}$ eutectic melting at $2170 \mathrm{~K}$. 
It has been proposed (see Refs, 1 through 4) that BWR fuel bundle reconfiguration effects and altered thermalnydraulic conditions drastically reduce overall bundle oxidation. Specifically, a governing assumption of early versions of the IDCOR MAAP-BWR code (Refs. 1 and 2) is that when melt relocation occurs, Zircaloy oxidation is substantially reduced or prevented. The conceptual basis for this viewpoint is illustrated in Figure 6-4, where cladding melting and relocation in the center assembiy is assumed to lead to a blocked fuel bundle. For complete blockages, steam pressurization below the blockage would result in diversion of residual water to adjacent unblocked assemblies. As a result, boil off and further oxidation in degraded BWR fuel assemblies was presumed terminated upon downward melt relocation, for Zircaloy oxidation models first incorporated in the MAPP-BWR code. The validity of this hypothesis hinges on two key assumptions, complete of flow area blockage upon melt relocation and maintenance of BWR channel box integrity. The NRC-SFD test results are examined here relative to these assumptions.

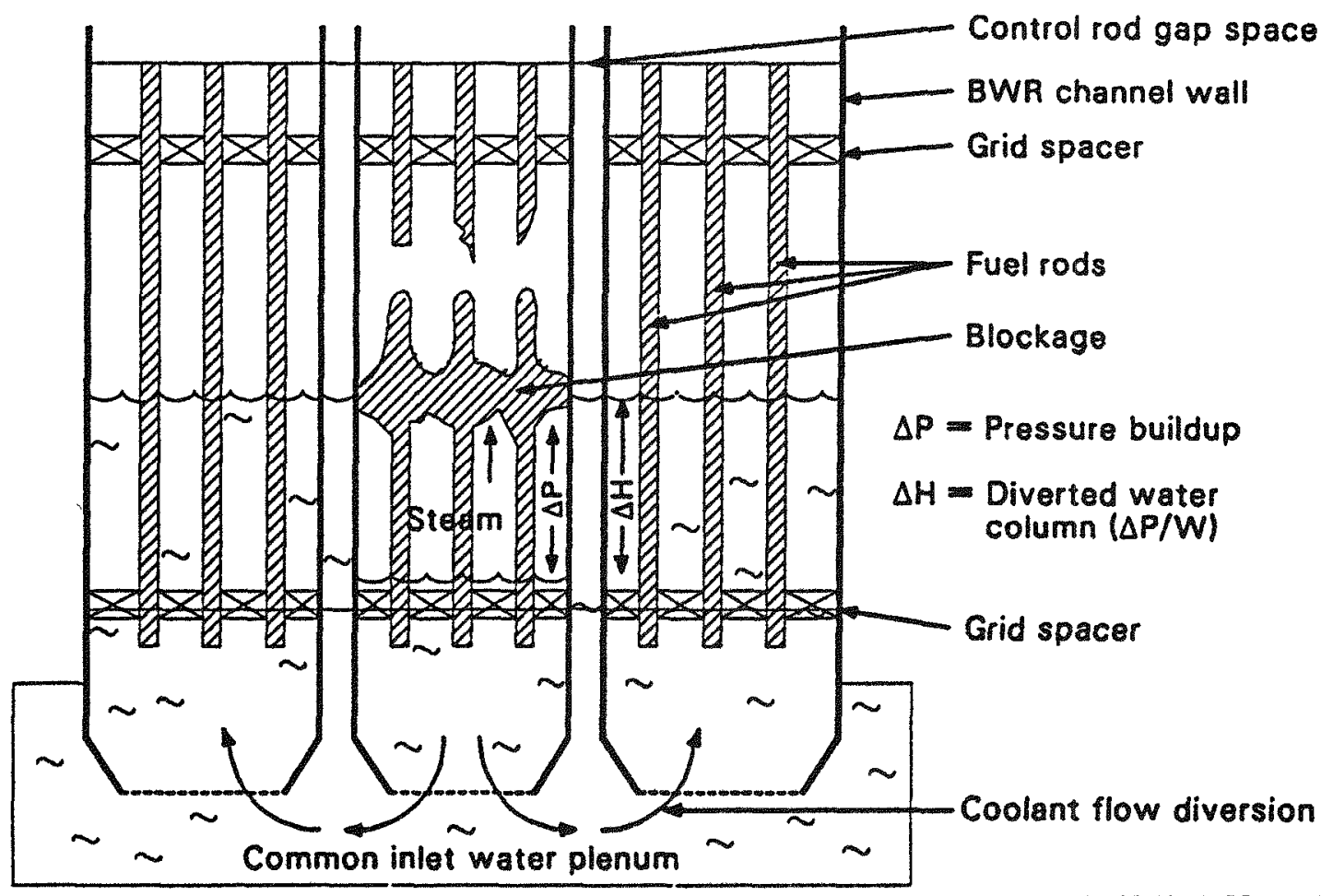

5267 AWC-0780.02

Figure 6-4. Illustration of original IDCOR BWR-MAPP blockage/coolant diversion hypothesis. 
a) Bundle Blockage/Coolant Diversion. Although posttest examination of the NRC-SFD test bundles revealed extensive flow area blockage, the degree of such blockage was not sufficient to prevent steam access to the reconfigured test bundles. Figure 6-5 illustrates the extent of flow area degradation noted in the PBF-SFD tests, based on posttest examination of the sectioned bundles. The salient feature to note is that some residual open flow area remained for continued steam access throughout the test. The same is true for the NRU and DF-4 test bundies.

The compressible isentropic flow equations can be used to assess the degree of flow-area constriction required for flow deversion in true BWR geometry; where an estimate is made of the differential pressure necessary to force steam flow through the blockage orifice illustrated in Figure 6-6. The mass flow rate per unit area for subsonic conditions can be expressed as:

$$
\dot{\mathrm{m}}_{0} / \mathrm{A}_{0}=\left(\frac{\mathrm{P}_{2}}{\mathrm{P}_{1}}\right)^{1 / \gamma}\left\{\frac{2 \gamma}{\gamma-1} \rho_{1} \mathrm{P}_{1} \mathrm{~B}_{\mathrm{c}}\left[1-\left(\frac{\mathrm{P}_{2}}{\mathrm{P}_{1}}\right)\right]^{(\gamma-1) / \gamma}\right\}^{1 / 2}
$$

where

$$
\begin{aligned}
& A_{0}=\text { minimum flow area, } \mathrm{cm}^{2} \\
& g_{C}=\text { conversion factor, } \mathrm{g} \mathrm{cm} / \mathrm{s}^{2} \text { dyne } \\
& \ddot{p}=\text { isentropic exponent }=c_{p} / C_{v_{2}} \\
& P_{1}=\text { upstream pressure, dynes } / \mathrm{cm}^{2} \\
& P_{2}=\text { downstream pressure, dynes } / \mathrm{cm}^{2} \\
& \rho_{1}=\text { upstream density, } \mathrm{g} / \mathrm{cm}^{3} \text {. }
\end{aligned}
$$

Inspection of the above equation indicates that the steam flow rate through a blockage orifice $\left(A_{0}\right)$ is governed by the difference between the upstream and downstream pressures. Using steam properties at $1000 \mathrm{psi}$ $\left(6.9 \mathrm{MPa}, 6.9 \mathrm{E}+7\right.$ dynes $\left./ \mathrm{cm}^{2}\right)$, the following choked flow conditions are estimated as a function of differential pressure:

$$
\begin{array}{cc}
\Delta \mathrm{P}, \mathrm{psi} & \mathrm{m} / \mathrm{A}_{0}, \mathrm{~g} / \mathrm{cm}^{2} \mathrm{~s} \\
\cline { 2 - 2 } 2.0 & 100 \\
1.0 & 70 \\
0.1 & 22
\end{array}
$$

100
70
22

Noting that the nominal makeup flow rates are about $0.6 \mathrm{~g} / \mathrm{s}$ for the PBF-SFD 1-1 and 1-4 tests, flow-area blockages in excess of 98-percent would be required to satisfy choked flow and bundle pressurization conditions. Although some uncertainty exists relative to the specification of a degraded flow area from posttest metallographic examinations, such extreme blockage conditions are not indicated from the available NRC-SFD test data. 


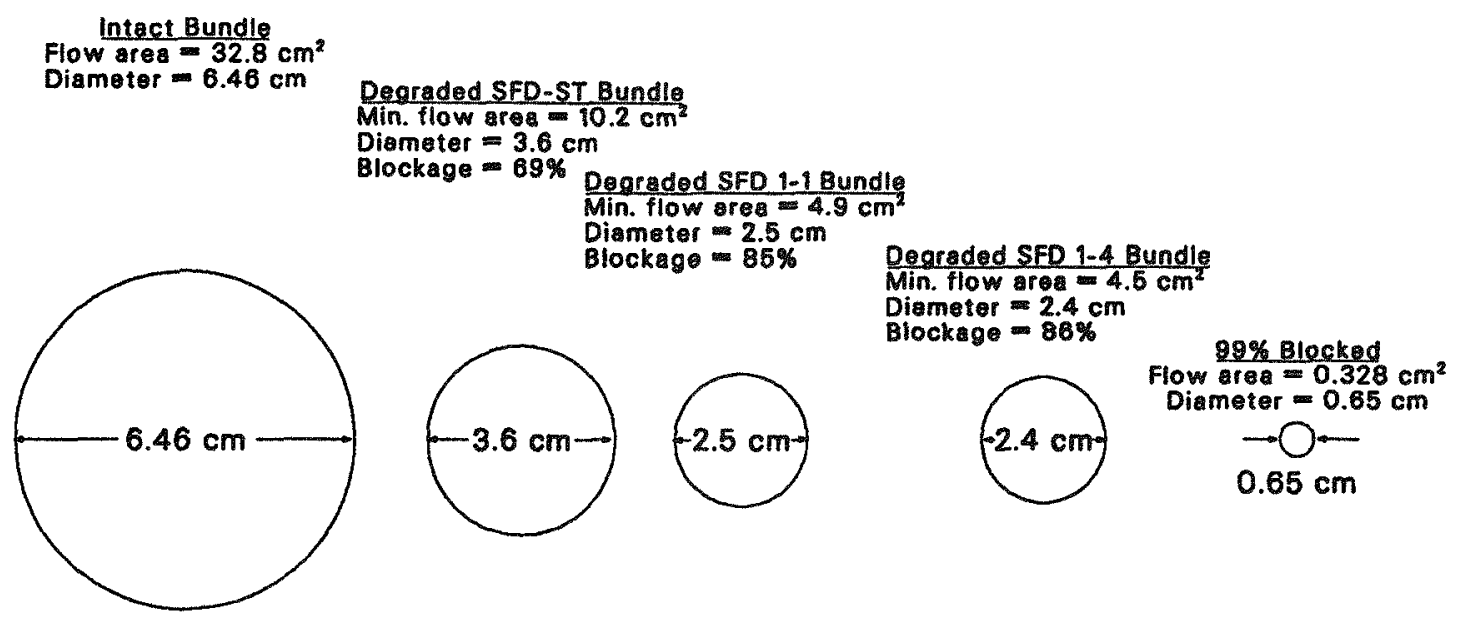

5267 AWC-0780-06

Figure 6-5. Comparison of flow-area reduction noted in the PBF-SFD tests.

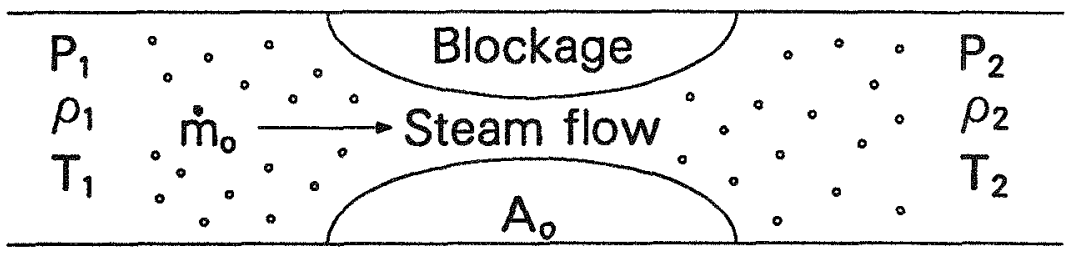

Figure 6-6. Illustration of isentropic compressible flow through a blockage orifice. 
It is also noted from inspection of Table 6-2 that steam flow and associated $\mathrm{H}_{2}$-generation continued throughout the test transients, and that for steam-starved conditions the makeup flow was nearly fully consumed in the oxidation process. For the steam-rich PBF-ST experiment however, Zircaloy oxidation was essentially complete early in the test transient, so that the excess makeup coolant to the bundle could not experience futher reaction with the fully-oxidized Zircaloy. It is also noted that only 68-percent of the total steam flow to the DF-4 bundle was consumed in oxidation, which is due to the combined effects of flow partitioning between the control blade and fueled regions of the bundle, as well as early Zircaloy channel box relocation. If oniy the steam flow to the fueled region is considered, the fraction of the makup flow consumed in bundle oxidation is about 86-percent.

TABLE 6-2. Summary of steam consumption by Lircaloy oxidation

\begin{tabular}{|c|c|c|c|c|}
\hline Test (Environment) & $\begin{array}{l}\text { Test, } \\
\underline{H}_{2, g}\end{array}$ & $\begin{array}{l}\text { Makeup } \\
\text { Flow,g/s }\end{array}$ & $\begin{array}{l}\text { Time at } \\
T>1700, \mathrm{~s} \\
\end{array}$ & $\begin{array}{l}\text { Percent } \mathrm{H}_{2} \mathrm{O} \\
\text { Consumed by Zrya }\end{array}$ \\
\hline PBF ST (Steam Rich) & 172 & $\simeq 16$ & $\simeq 600$ & $\simeq 16$ \\
\hline PBF 1-1 (Steam Starved) & 54 & $\simeq 0.6$ & $\approx 600$ & 100 \\
\hline PBF 1-4 (Steam Starved) & $86^{\circ}$ & $\simeq 0.0$ & $=750$ & 100 \\
\hline FLHT-2 (Steam Starved) & 44 & $=1.4$ & $\simeq 250$ & 100 \\
\hline FLHT-4 (Steam Starved) & 240 & $\simeq 1.26$ & $\approx 1800$ & $\simeq 94$ \\
\hline FLHT-5 (Steam Starved) & 340 & $\simeq 1.23$ & $\approx 3000$ & $\simeq 83$ \\
\hline DF-4 (Steam Starved) & 38 & $\simeq 0.88^{b}$ & $\simeq 570$ & $\simeq 68$ \\
\hline DF-4 (Steam Starved) & 38 & $\approx 0.70 \mathrm{C}$ & $\simeq 570$ & $\simeq 86$ \\
\hline
\end{tabular}

a. Percent $\mathrm{H}_{2} \mathrm{O}$ Consumed equals $\mathrm{H}_{2}$ generated divided by Makeup Flow $x$ ( $T$ ime at $\mathrm{T}>1700 \mathrm{~K}$ ) as equivalent $\mathrm{H}_{2}$

b. Total makeup flow to bundle (blade and fuel region)

c. Makeup flow to fuel region only

The hypothesis of complete flow-area blockage is based on the concept of coherent melt relocation and refreezing. However, posttest metallurgical observations on material interactions, melt relocation, and debris refreezing indicate that relocation and refreezing of core materials is inherently incoherent. As illustrated in Figure $\overline{0}-7$, inhomogenous behavior can be partially attributed to the presence of different core materials with a wide range of melting points and eutectic temperatures. The formation of such eutectics allows for a highly nonuniform melting and relocation process that occurs over many minutes. As a result adaquate time appears available for Zircaloy bearing melt to oxidize during melt relocation. 


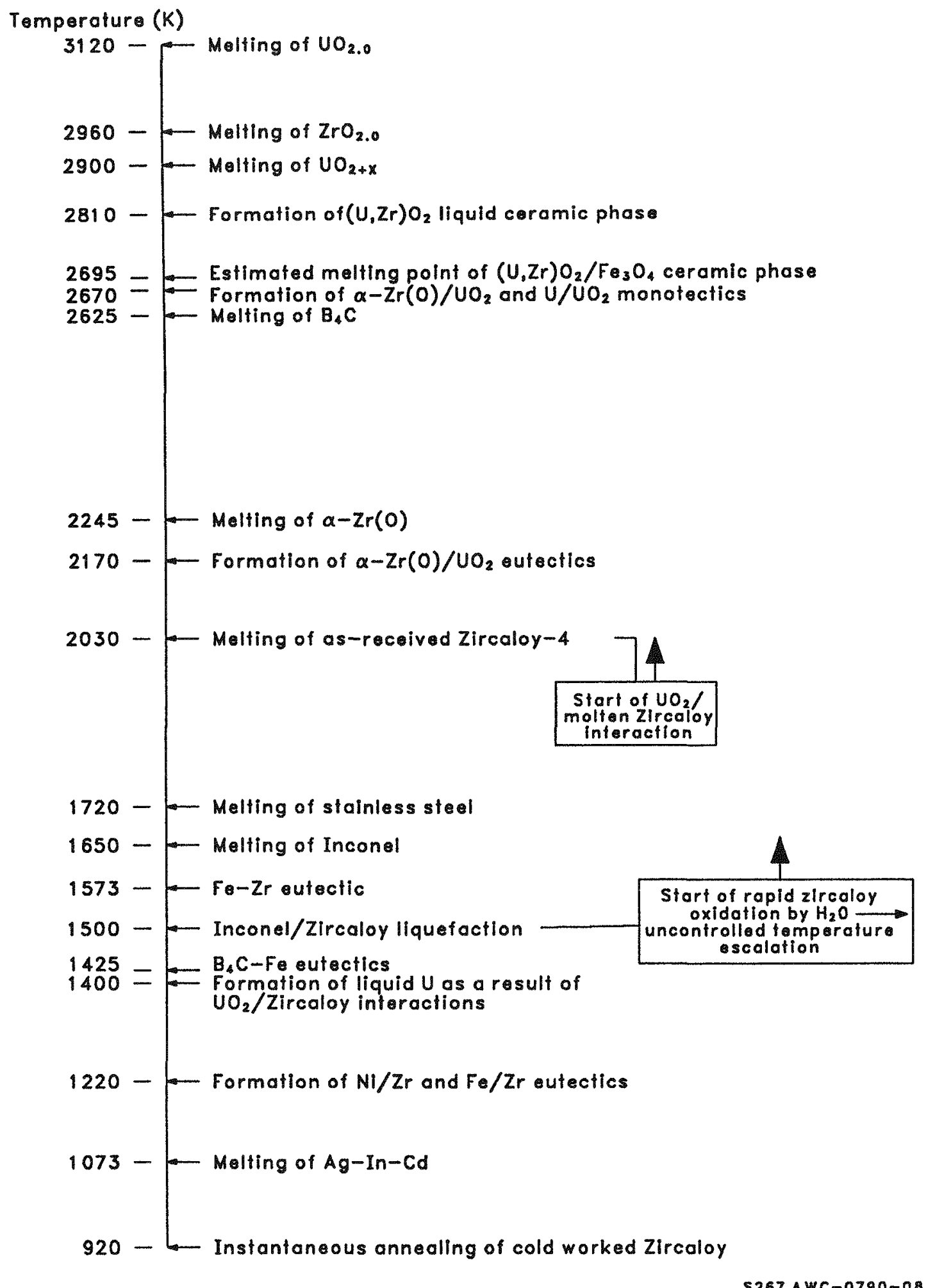

S267 AWC $-0790-08$

Figure 6-7. Summary of key melting points and eutectic temperatures that can occur during severe LWR accidents. 
Besides evidence of incomplete flow-area blockage and non-homogenous melt relocation, the NRC-SFD data also indicate non-coherent temperatures within test bundles which helps promote observed incoherent melt-relocation behavior. Figures 6-8 and 6-9 present a comparison of the NRU-FLHT-4 and SFD 1-1 rod cladding themocouple data at different rod positions at the same axial elevation. The data indicate that at the same axial elevation/time period, variations in rod temperatures in excess of $100 \mathrm{~K}$ existed, which escalate to higher temperature differences at later times. This escalation in asymmetric bundle heating can be attributed to the autocatalytic nature of Zircaloy oxidation, which can be visualized as follows. One section of the bundle is initially at a temperature higher than another. If the bundle is steam-starved, most of the steam will be consumed by the higher-temperature Zircaloy. Oxidation drives the hotter Zircaloy to higher temperatures, which consumes a greater portion of the steam, driving local temperatures higher, and so on. The autocatalytic nature of Zircaloy oxidation therefore appears to have contributed to asymmetric bundle heatup and incoherent melt relocation behavior.

Although asymmetry is not generally modeled in severe accident analysis codes, it can have a pronounced effect on local melting and result in asymmetric melt relocation, as indicated by the posttest bundle examination data. Steep temperature gradients were also noted from examinations of the TMI-2 core components $(5,6)$ as evidenced by the melting behavior of different core materials that were near each other and by differences in the prior molten state of a single material across an individual fuel assembly. These temperature differences were apparently the result of variations in localized steam flow and material interactions in the degraded TMI-2 core, and resulted in significant differences in localized Zircaloy oxidation, hydriding, and phase changes.

b) BWR Channel Box Survival. The IDCOR BWR-MAAP flow diversion arguments illustrated in Figure 6-4, also requires that the $B W R$ channel box (thickness being 0.08 to $0.1 \mathrm{in.)}$ remain intact during core degradation. Evidence of BWR Zircaloy channel box behavior can be noted from the ACRR DF-4 test, which simulated control rod and channel box geometry. Posttest examination (see Figure 5-3) of the DF-4 test bundle revealed that all but the lower 10-percent of the channel box had melted, leaving only slight traces of any channel box remnants in the upper regions of the bundle. The DF -4 observations of BWR Zircaloy channel box oxidation and failure are in basic agreement with recent results of the CORA absorber rod experiments $(7,8)$. These tests indicate channel box failure due to a combination of eutectic interaction between $\mathrm{B}_{4} \mathrm{C}-\mathrm{Fe}$ melt and Lircaloy, as well as oxidation induced channel box heatup and degradation. The Zr-Fe eutectic illustrated in Figure 6-10, is largely responsible for early destruction of the Zircaloy channel box.

The implications of the ACRR DF-4 and CORA tests are that BWR channel box oxidation and failure can be expected, which would largely negate the IOCOR assumption of segregated BWR assembly geometry upon which blockage/flow diversion arguments hinge. As illustrated in Figure o-11, failure of channel box would reestablish flow through a degraded bundle, and allow for continued oxidation of rod stubs above the blockage region. 


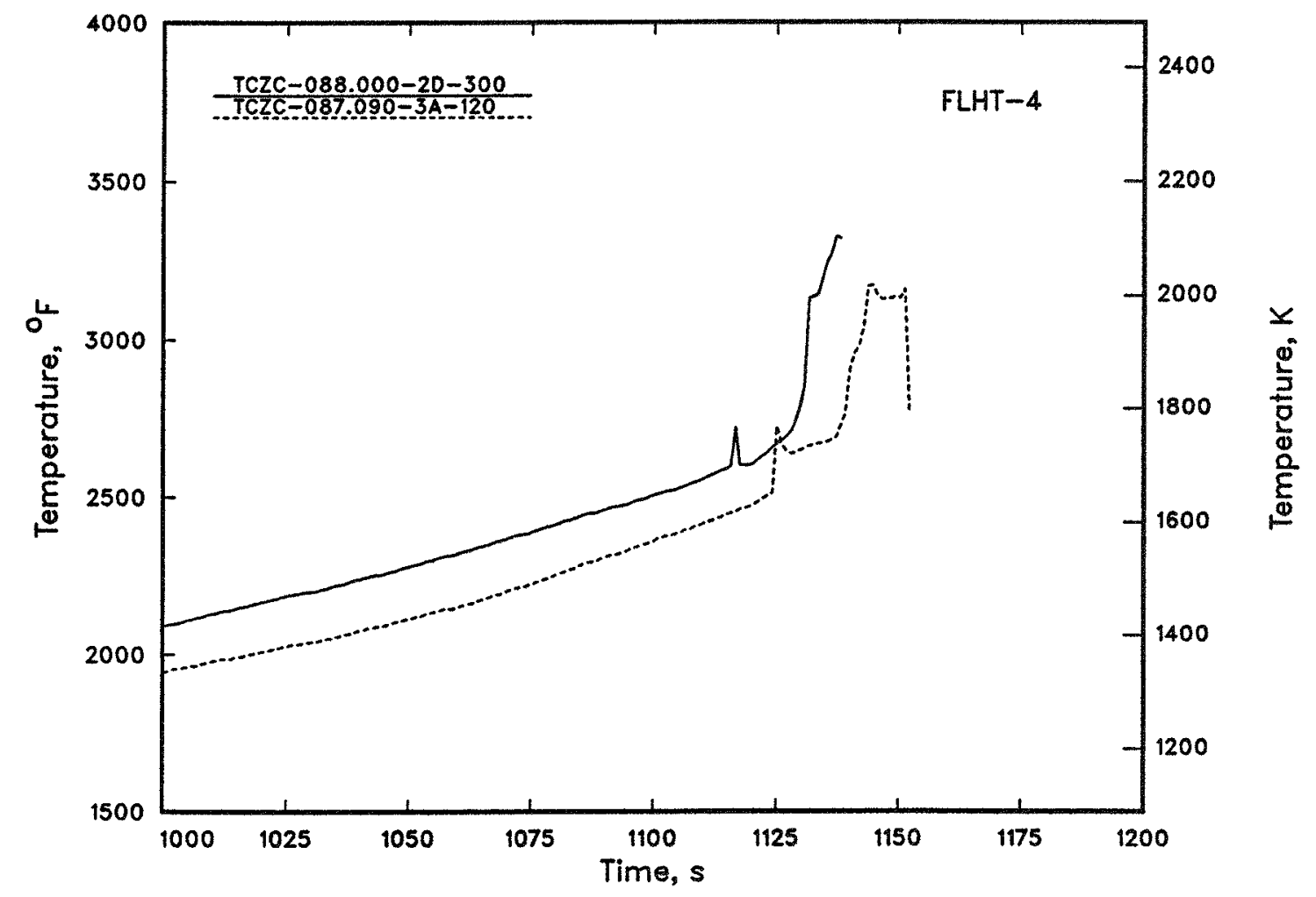

Figure 6-8. Illustration of asymmetric rod temperature condition in the NRU-FLHT-4 test bundle.

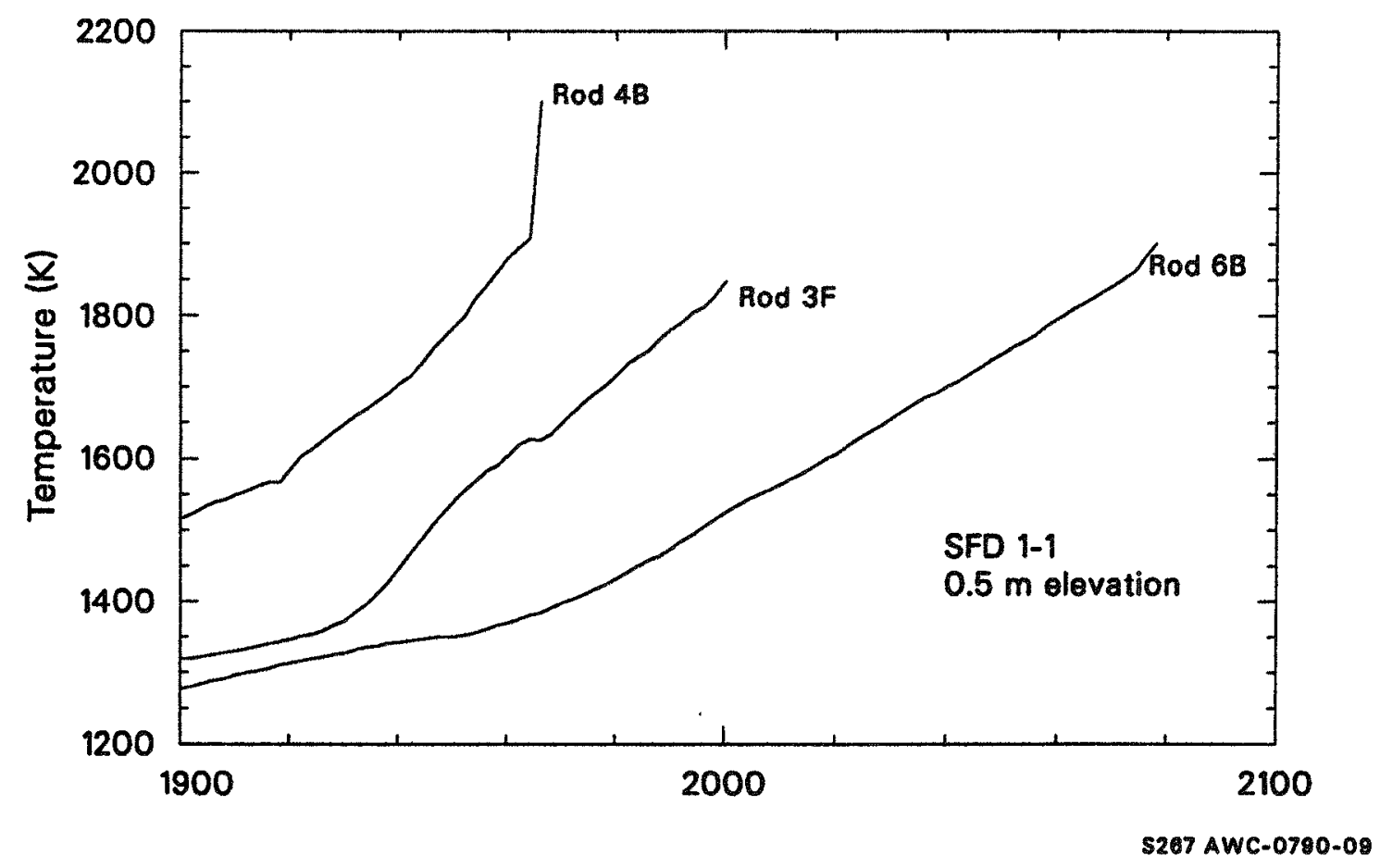

Figure 6-9. Illustration of asymmetric rod temperature conditions in the SFD 1-1 test bundle. 


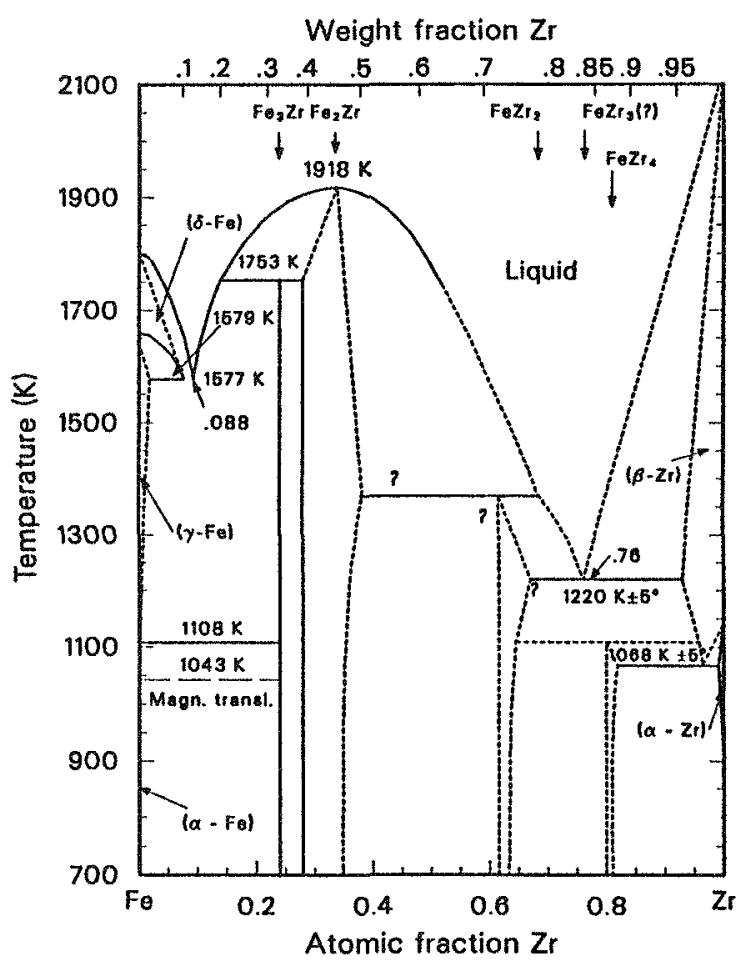

\$267 AWC-0790-10

Figure 6-10. Fe-Zr binary phase diagram.

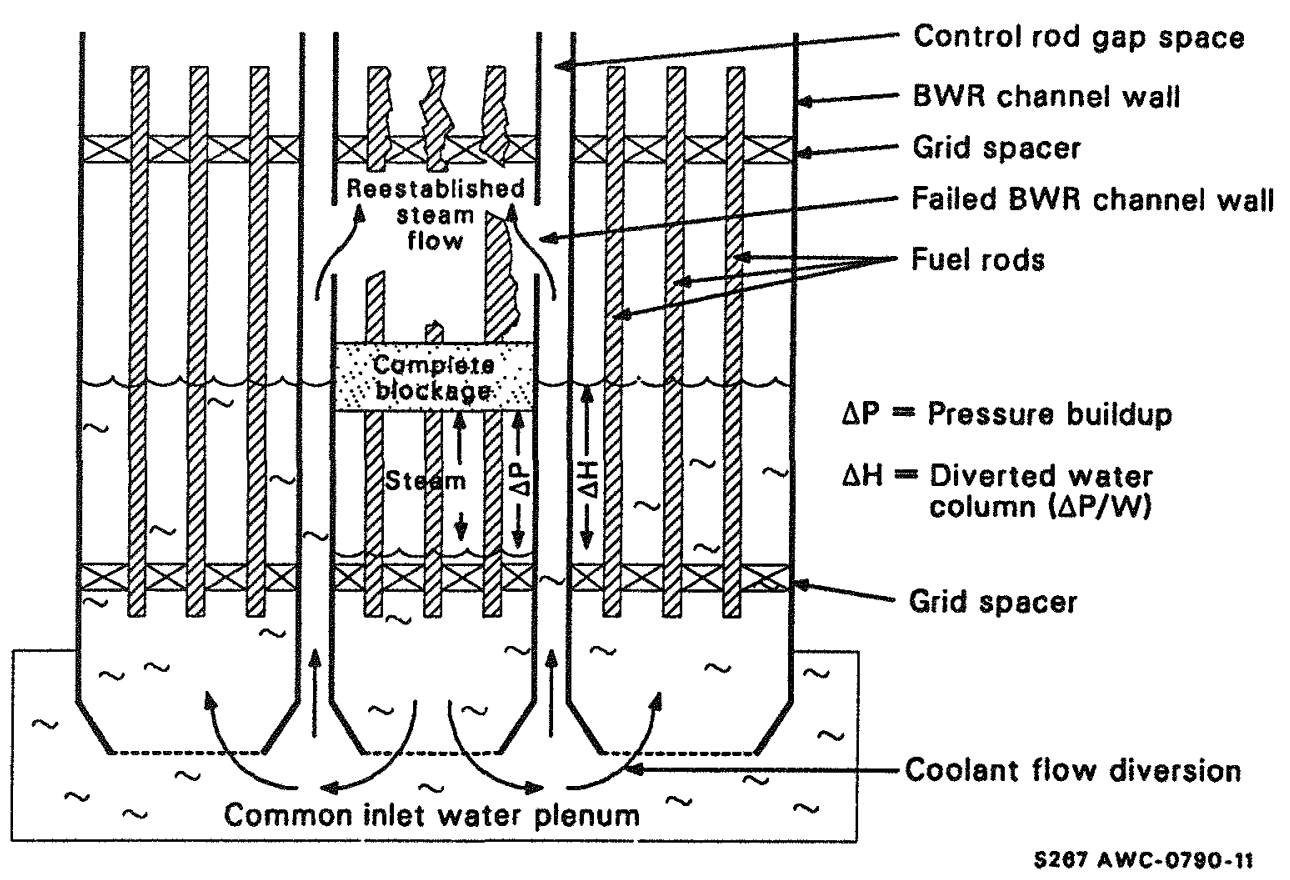

Figure 6-11. Illustration of reestablished steam flow through a failed channel wall in a degraded/alocked BWR fuel assembly. 


\subsection{References}

1. R. Henry, J. Gabor, M. Kenton, R. MacDonald, and A. Sharon, "Evaluations of Hydrogen Generation During Core Heatup with an Intact Geometry", Proc. Inter. Mtg. on LWR Severe Accident Evaluation, Cambridge, MA, (August 28-September 1, 1983).

2. J. R. Gabor ad R. E. Henry, "The MAAP-BWR Severe Accident Analysis Code", Proc. Intern. Mtg. on LWR Severe Accident Evaluation, Cambridge, MA, (August 28-September 1, 1983).

3. A. Sharon, J.R. Gabor, and R. E. Henry, "Simulation of the Severe Fuel Damage Tests (SFD) Using the Modular Accident Analysis Program (MAAP)", Proc. Intern. Mtg. on Thermal Reactor Safety, San Diego, CA, (February $2-6,1986$ )

4. A. Sharon, "Comparison Between the PBF-SFD Fuel Bundle and a BWR Channel Behavior in Degraded Conditions", Proc. 24th National Heat Transfer Conf., Pittsburgh, PA, AICHE Symposium Series 257 TVOT. 83), pp. 307-313, (August 9-17,1 1987).

5. E. R. Carlson and B. A. Cook, "Chemical Interaction Between Core and Structural Materials", Proc. 1st Intern. Information iltg. on the TMI -2 Accident, CONF-8510166, Germantown, MD (October 1985).

6. C. S. Ulsen, S. M. Jensen, E. R. Carlson, and B. A. Cook, "Materials Interactions and Temperatures in the Three Mile Island Unit-2 Core", J. Nucl. Tech. (87), pp. 57-96, (August 1989).

7. S. Hagen, P. Hoffman, G. Schanz, and L. Sepold; "Results of the CORA Experiments on Severe Fuel Damage with and Without Absorber Material", Proc. 26th National Heat Transfer Conf., Philadelphia, PA (August $6-9,1989$ ).

8. S. Hagan, L. Sepold, P. Hoffman, and G. Schanz, "Out-of-Pile Experiments on the Meltdown Behavior of LWR Fuel Elements: Influence of Absorber Materials", Intern. Conf. on Thermal Reactor Safety, Avignon, France, (0ctober 2-7, 1988). 


\section{CONCLUSIONS}

Although the NRC-Severe Fuel Damage tests were conducted over a wide range of test conditions, a number of common findings were observed which have a significant impact on the in-vessel hydrogen source term for severe accidents. The principal findings of this data are summerized in Table 7-1.

With respect to Lircaloy melt effects, on-line measurements of hydrogen production for the PBF-SFD, NRU-FLHT, and SNL DF-4 tests indicate that the major portion of hydrogen generation occurred after melt temperatures were reached, based upon a comparison of on-line $\mathrm{H}_{2}$ and cladding thermocouple data. These findings are corroborated by post-test metallurgical observations. Extensive metallurgraphy indicates that Zircaloy-bearing melt continued to oxidize during and following melt relocation. Arguments for cutoff or deminished hydrogen generation upon Zircaloy are therefore not supported by the NRC-SFD data.

Concerning the question of bundle reconfiguration and potential blockage effects, the PBF-SFD, DF-4 and NRU-FLHT on-line data indicate that hydrogen generation continued during and following melt relocation. The PBF-SFD and DF-4 post-test metallurgical data also indicate oxidation must have continued during and after melt relocation, from detailed examination of once-molten Zircaloy-bearing debris. ATthough the PBF-SFD, DF-4 and NRU-FLHT bundle inspections indicate extensive flow-area blockage, none of the tests indicated flow area blockages in excess of 98-99-percent required for choked steam flow. These observations are at odds with the IDCOR MAAP-BWR code assumption of complete flow area blockage upon melt relocation and prevention of steam access to degraded BWR fuel bundles. Indeed, no sigificant retardation of $\mathrm{H}_{2}$ generation was noted in any of the NRC-SFD tests after melt relocation and partical flow area blockage had occured.

Asymmetrical bundle heatup conditions were al so noted from thermocouple data. Metallurgical observations of material interaction, melt relocation, and debris refreezing likewise indicate non-homogenous melt behavior and incoherent melt refreezing. Such incoherency also results from the presence of different core materials with a wide range of melt eutectics that can form. As a result, adequate time appears available for materials to oxidize during melt relocation. Although total blockages may ultimately occur at the late stages of a severe accident as a large amount of melt accumulates in the lower regions of a BWR fuel assembly; by the time such a situation has been attained a high degree of melt oxidation would have already occurred, as evidenced by the NRC-SFD data.

Information on the influence of BRW control rod and channel box effects was primarily accessed from the DF-4 experiment, which simulated BWR geometry. Results indicate eariy channel box failures due to control rod melt attack on the Zircaloy can wall. Radiographic and destructive post-test examination of the test bundle revealed that all but the lower 10-percent of the channel box had melted, leaving only slight traces of any oxide channel box remnants in the upper regions of the bundle. The DF -4 observations of BWR Zircaloy channel box oxidation and failure are in basic agreement with results of the CORA absorber rod experiments. 
The CORA tests indicate channel box failure due to a combination of eutectic interaction between Fe melt and Zircaloy, as well as oxidation induced channel box degradation. It is also noted that post-test examinations of the PBF-SFD and NRU-FLHT bundles indicated extensive oxidation, eutectic induced melting, and failure of the Zircaloy liner material that shrouded these test bundies. These data thus indicate that oxidation and failure of a BWR Zircaloy channel box can be expected during severe accidents. Destruction of the BWR channel box would allow for steam access to degraded bundles. In summary, observation from the NRC-SFD tests do not indicate limitations on $\mathrm{H}_{2}$ generation by core degradation.

TABLE 7-1. Principal findings on Zircaloy oxidation and hydrogen generation behavior

Intact Rod Geometry Effects

- PBF-SFD and NRU-FLHT test data indicate enhanced Zircaloy oxidation at temperatures in excess of $1700 \mathrm{~K}$.

- The PBF-SFD-ST data indicate that $\mathrm{UO}_{2}$ fuel oxidation occurs for steam-rich enviornments, which is supported by findings of hyperstocheometric fuel from retrieved TMI-2 debris samples.

\section{Zircaloy Melt Effects}

- On-line PBF-SFD, DF-4 and NRU-FLHT data indicate continued bydrogen generation after onset of Zircaloy melting.

- Post-test metallography for the PBF-SFD, NRU-FLHT and DF-4 tests indicate extensive oxidation of Zircaloy bearing melt debris.

- PBF-SFD and NRU-FLHT on-line data and metallographic observations indicate non-uniform bundle heatup and melt generation.

Bundle Reconfiguration Biockage Effects

- PBF-SFD, DF-4 and NRU-FLHT on line data indicate continued Zircaloy oxidation and hydrogen generation during and following melt relocation.

- PBF-SFD and NRU-FLHT metallographic data indicate extensive but incomplete flow-area blockage.

Loss of BWR Channel Box

- DF-4 test indicates early channel box failure by eutectic interaction with stainless-steel melt, which are supported by data from the CORA tests.

- PBF-SFD and NRU-FLHT metallographic data indicate oxidation and failure of the Zircaloy liner shrouding these test bundles. 


\section{BIBLIOGRAPHIC DATA SHEET}

(See instructions on the reverse)

\section{TITLE ANO SUBTITLE}

In-Vessel Zircaloy Oxidation/Hydrogen Generation Behavior During Severe Accidents

5 AUTHOR(S)

August $W$. Cronenberg

\section{U S. NUCLEAR REGULATORY COMMISSION I REPOAT NUMBE $A$}

(Asslgnod by NAC Add Vol, Supp, Rev.,

and Addendum Numbora, if sny I

NUREG/CR-5597

DATE REPORT PUBLISHED

\begin{tabular}{l|r} 
MONTH & YEA \\
ptember & 1990
\end{tabular}

4. FIN OR GRANT NUMBER

NRC - 04-86- 126

6 TYPE OF REPORT

Technica1

7. PERIOD COVERED (Inclusive Dates)

Sept 1986 - Sept 1990

8 PERFORMING ORGANIZATION - NAME AND ADDRESS (If NRC, provide Divesion, Office or Regron, $U S$ Nuclear Regulatory Commission, and mating addit ss if cantractor provide nome and mailing address.)

Engineering Science and Analysis

8100 Mountain Road N.E., Suite 220

Albuquerque, New Mexico 87110

9 SPONSORING ORGANIZATION - NAME AND ADDRESS IIf NRC, tvpe "Same as above", "I comtracior, provide NAC Division, Otfice or Region U S Nucteat Requiatory Commission. and mathing address.)

Division of Systems Research

Office of Nuclear Regulatory Research

U.S. Nuclear Regulatory Commission

Washington, D.C. 20555

10. SUPPLEMENTARY NOTES

11. ABSTRACT (200 words or less)

In-vessel Zircaloy oxidation and hydrogen generation data from various U. S. Nuclear Regulatory Commission severe-fuel damage test programs are presented and compared, where the effects of zircaloy melting, bundle reconfiguration, and bundle quenching by reflooding are assessed for common findings. The experiments evaluated include fuel bundles incorporating fresh and previously irradiated fuel rods, as we11 as control rods. Findings indicate that the extent of bundle oxidation is largely controlled by steam supply conditions and that high rates of hydrogen generation continued after melt formation and relocation. Likewise, no retardation of hydrogen generation was noted for experiments which incorporated control rods. Metallographic findings indicate extensive oxidation of once-molten Zircaloy bearing test debris. Such test results indicate no apparent limitations to Zircaloy oxidation for fuel bundles subjected to severe-accident coolant-bojloff conditions.

Hydrogen generation, Zircaloy oxidation, severe accidents, in-pile experiments, cladding oxidation, core meltdown

Unlimited I4 SECURITY CLASSIFICATION TThis Pagel

Unclassified (Thus Report)

Unclassified 15. NUMBER OF PAGES 